\title{
Cannabinoid Hyperemesis
}

\author{
Joseph V. Pergolizzi Jr. Jo Ann LeQuang John F. Bisney \\ NEMA Research, Inc., Naples, FL, USA
}

\section{Keywords}

Cannabis - Marijuana - Cannabinoid hyperemesis .

Cannabinoid vomiting syndrome $\cdot$ Hyperemesis $\cdot$ Cyclic vomiting

\begin{abstract}
Cannabinoid hyperemesis syndrome (CHS) is a paradoxical condition in which a long-term cannabis user suffers an episode of intractable vomiting that may last days separated by longer asymptomatic periods of weeks or months. Cannabinoids are often utilized for their antiemetic properties, so CHS can be a puzzling condition, and the diagnosis of $\mathrm{CHS}$ may be disputed by patients. Unlike other cyclic vomiting syndromes, CHS can be relieved by hot showers or topical capsaicin. Abstinence from cannabinoids causes CHS to resolve, sometimes in a matter of days or hours. Marijuana users as well as many clinicians are not aware of CHS, and patients may undergo unnecessary tests, scans, and other procedures to get an accurate diagnosis. Symptoms may be severe enough to require hospitalization. With liberalization of marijuana laws and favorable public opinion about the healing properties of cannabis, CHS may be more frequently observed in clinical practice.

(c) 2018 The Author(s) Published by S. Karger AG, Basel
\end{abstract}

\section{Introduction}

Cannabinoid hyperemesis syndrome (CHS) involves episodic cyclic vomiting that occurs in some cannabis users. Typical symptoms include intractable nausea and vomiting, refractory to conventional antiemetic therapy, often accompanied by abdominal pain. Other symptoms may include sweating, flushing, thirst, weight loss, and changes in body temperature. Patients may find relief by bathing in hot water. CHS resolves when cannabinoids are discontinued $[1,2]$. Since marijuana is recommended as an antiemetic to chemotherapy patients, CHS seems paradoxical, but cannabinoids can have both proemetic as well as antiemetic effects.

In America, 22.2 million Americans reportedly used some form of cannabinoids in the past month [3]. Since 2009, when the US Department of Justice published a memo to the effect that it would not prosecute users or sellers of medical marijuana who complied with their local state laws [4], marijuana use increased and with it, the rate of persistent vomiting increased $17.9 \%$ over prelegalization rates [5]. The Drug Abuse Warning Network (DAWN) states that marijuana mentions (the number of times "marijuana" is mentioned in a medical record) have increased 21\% from 2009 to 2011 [3]. Since 2009, the rate of persistent vomiting has increased significantly and continues to increase at about $8 \%$ a year [5]. CHS cases have been reported from all over the world. This suggests 
that this once "rare" condition is going to emerge as an increasingly common presentation in emergency departments (ED) and clinics. CHS is not trivial; there are fatal cases of CHS (as cause of death or contributing to death) reported in the literature.

\section{Methods}

The objective of our research was to establish a clinically meaningful description of CHS and its presentation, to evaluate diagnostic challenges in identifying this syndrome, and to describe effective treatment options. In mid-May 2018, the PubMed database of the National Institute of Medicine was searched for clinical trials, clinical studies, and case reports of "cannabinoid hyperemesis" or "cannabis hyperemesis" or "marijuana hyperemesis." Once duplicates were removed, a total of 105 articles were reviewed. Articles that were not in English were excluded as were case reports that did not report the age, sex, presentation, diagnosis, and treatment of the patient. In some cases, bibliographies of articles were searched. Case reports were summarized in Table 2 and case series presented in the narrative text. In some cases, the bibliographies of these articles were also searched.

\section{Results}

\section{History}

The first description of CHS in the literature came from Allen et al. [1] in Australia in 2004, when they reported a case series of 19 chronic marijuana users who presented with cyclic vomiting. Since then, cases have been reported from France, Australia, the Netherlands, Canada, Spain, New Zealand, as well as other countries. The first case report from Germany was published in 2011 [6]; the first case from Puerto Rico was published in 2015 [7]. While further study is needed, it appears that those who develop CHS are typically nonmedical users who often have used cannabis products regularly for a period of years [8]. Since marijuana has been widely used for centuries, the question arises as to why CHS seems to have only recently emerged as a medical issue. The authors can only speculate that it may involve recent changes in cannabis cultivation and production that have resulted in historically high tetrahydrocannabinol (THC) concentrations. The highest THC concentrations are found in buds, then leaves (about 1/10th as much by weight), and even less in stalks [9]. Advances in breeding the plants, raising them under high-intensity lights under optimally controlled conditions, and the sale of buds with stalks, stems, and leaves almost entirely removed has led to unprecedented potency in current marijuana products
[10]. Furthermore, relaxed legal restrictions and a favorable public opinion about the medical and recreational properties of cannabis may have increased use. Thus, consumption of today's marijuana exposes users to much higher levels of THC than in the past. A study from the Netherlands found that THC concentrations in cannabis products sold at retail outlets from 2000 to $2015 \mathrm{had}$ roughly doubled from 2000 to 2015 [11]. New products on the market are even higher in THC: cannabis extracts (used for "dabbing") have more than triple the THC content of the buds or other plant parts commonly used for smoking (68.7 vs. $20.6 \%$ ) [12]. However, it is hard to discuss cannabinoids as if they were one single substance; even among botanical marijuana offerings, there are numerous varieties and diverse methods of consumption (smoking, "vaping," edibles).

\section{Description}

CHS is an episodic syndrome with vomiting episodes that last for $24-48 \mathrm{~h}$ at a time separated by asymptomatic periods that may last weeks or months [13]. During episodes, patients suffer severe nausea and intractable vomiting often accompanied by abdominal pain for which conventional antiemetic therapy (such as ondansetron, promethazine, and metoclopramide) offers no relief [14]. Protracted periods of vomiting (as often as 20 times a day) leaves some patients dehydrated, disoriented, and in electrolyte imbalance. Over time, unintentional weight loss may be reported. Few CHS patients associate their cannabinoid consumption with CHS symptoms. It appears that chronic marijuana use results in CHS only in certain susceptible patients, but it is not clear how to identify these patients in advance or stratify them for risk. It has been speculated that CHS occurs only in a subset of the patients who are susceptible to cyclic vomiting syndrome (CVS) and will not occur in those who do not already have a tendency to develop CVS [15].

\section{Pathogenesis}

Preclinical studies show that there are at least two Gprotein-coupled cannabinoid receptors, $\mathrm{CB} 1$ and $\mathrm{CB} 2$, whose activities have not been entirely elucidated. CB1 is expressed in the central nervous system (CNS) neurons, while CB2 is localized mainly in the lymphoid tissues of the periphery [16]. The body produces endogenous ligands for these $\mathrm{CB}$ receptors, of which two have been identified: $\mathrm{N}$-arachidonoylethanolamide (also known as anandamide) and 2-arachidonoylglycerol (2-AG), which are found in the brain and the gut [16]. After cellular reuptake, anandamide is metabolized by the fatty acid amide hydro-
Med Cannabis Cannabinoids 2018;1:73-95 DOI: 10.1159/000494992
Pergolizzi Jr./LeQuang/Bisney 
lase (FAAH) enzyme, while 2-AG is metabolized by a combination of monoacylglycerol lipase, other hydrolase enzymes, and FAAH. 2-AG is proemetic [17]. Anandamide has the greater affinity for the $\mathrm{CB}$ receptors, while 2-AG has the greater efficacy. (In this connection "affinity" may be defined as the ability of a substance to bind reversibly to its receptor, while "efficacy" means that it forces the greater number of available receptors to their active conformational state [16].) When activated, both CB1 and CB2 as G-protein-coupled cannabinoid receptors inhibit adenylyl cyclase [18]. CB1 receptors, located mainly in the brain, appear to decrease the release of serotonin when activated $[19,20]$. The transient receptor potential vanilloid 1 (TRPV1) receptor, located in the periphery along with certain areas of the CNS, may also play a role in CHS [21]. TRPV1 is a nonselective cation channel with calcium preference; it opens to ligand binding or stimulation. There is a high density of TRPV1 receptors in the area postrema known as the "trigger zone" for emesis [22]. Endocannabinoids (anandamide) along with exogenous cannabinoids (cannabidiol [CBD], cannabidivarin) are TRPV1 agonists [23, 24]. To complicate the picture, TRPV1 agonism appears to be proemetic when ligand concentration is low, but antiemetic when ligand concentration is high $[23,24]$. Extreme stimulation can desensitize TRPV1 and be proemetic [25]. TRPV1 desensitization may occur because signaling by substance P and CGRP has been disrupted, resulting in a lower density of substance $P$ receptors in the brain regions associated with vomiting $[25,26]$. Opening the TRPV1 channels may impair substance P signaling in the vomiting center of the brain by overstimulating TRPV1, which then results in antiemetic effects. Thus, desensitized TRPV1 receptors may promote emesis while opening TRPV1 channels may be antiemetic.

Endogenous cannabinoids or endocannabinoids may also play a role in CHS. Endocannabinoids are arachidonic acid derivatives that are biochemically similar to anandamide and 2-AG and likewise bind to CB1 and CB2 $[27,28]$. Endocannabinoids may be neuromodulators or neurotransmitters [29]. Once they are activated, anandamide and 2-AG have different pathways for biosynthesis and subsequent degradation, in that anandamide is metabolized mainly by FAAH while $2-\mathrm{AG}$ is metabolized via monoacylglycerol lipase [30]. Endocannabinoids are present in the CNS and enteric nervous systems and are released locally on demand by neuronal signaling; they are released in small amounts and become rapidly inactivated [28]. Unlike other neurotransmitters like serotonin or dopamine, endocannabinoids are not stored in the vesicles but are rather synthesized "on demand" in postsyn- aptic neurons via retrograde signaling, allowing them to diffuse back to the presynaptic nerve terminals where they can stimulate the CB1 receptors and, in that way, inhibit the release of other neurotransmitters [16].

Botanical marijuana contains well over 400 different chemicals, of which 60 might be labeled cannabinoids [16]. The primary active compound in exogenous cannabinoids is THC which is metabolized in the liver by oxidative and hydroxylation reactions via the CYP2C isoenzyme subfamily [31]. In simplistic terms, THC acts as a $\mathrm{CB} 1$ and $\mathrm{CB} 2$ receptor agonist with broad-spectrum antiemetic properties [16]. Because of variations in marijuana products, an accurate value for the half-life of THC has been difficult to determine but has been estimated at $20-30 \mathrm{~h}$ [32]. THC is excreted through the feces $(60 \%$ to $85 \%)$ and urine (20\% to $35 \%)$ as acid metabolites $[32,33$. However, THC is highly lipophilic and accumulates in adipose tissue $[32,34]$. These stored THC reserves have been associated with a "reintoxication" effect that can occur during periods of stress or prolonged fasting, when increased lipolysis releases these reserves stored in the fat [35]. Individuals who have used cannabis products regularly over a long period of time would be expected to have large lipid reserves of THC which might be released during periods of stress. THC may act as an antiemetic in the CNS because of reduced substance $P$ signaling, which occurs during active consumption of marijuana. However, with accumulation of THC in the body fat over time, THC reserves may eventually achieve sufficiently high concentrations in the CNS to stimulate TRPV1 channels to their emetic threshold. This would explain why cannabinoid abstinence resolves symptoms [36]. It must also be noted that THC binds to CB1 receptors in the gastrointestinal (GI) tract, causing gastroparesis, which in and of itself can cause nausea and vomiting. The effect of THC on the CB1 receptors warrants greater study. It has been suggested that THC might over time downregulate the CB1 receptors, reducing their functionality in such a way that the normal agonistic activity of THC at CB1 reverses and becomes antagonistic and this results in emesis [7]. It is unclear if and to what extent prolonged THC exposure may sensitize CB1 receptors.

Other cannabinoids have been implicated in the pathogenesis of CHS, such as CBD and cannabigerol (CBG). It has been observed that $\mathrm{CBD}$ is antiemetic at low doses but proemetic at high doses [37]. Furthermore, CBG may be able to reverse the antiemetic properties of CBD [38]. This would mean that the proemetic effects observed in CHS involve an interplay of processes, possibly including high levels of CBD reversed by CBG [39]. 
It is not known if certain varieties of botanical marijuana are more likely to produce CHS than others. Furthermore, the role of cytochrome (CYP) P450 metabolism and genetic polymorphisms might play a role in terms of why certain individuals are susceptible to CHS. Genetic polymorphisms of the cytochrome P (CYP) 450 enzyme system, such as CYP2CP, CYP2C19, or CYP3A4 could cause an individual to accumulate excessive amounts of cannabinoid metabolite(s) which might promote vomiting. This is a complex area that warrants further study. For example, THC has two main metabolites (11-hydroxy-delta9-tetrahydrocannabinol or 11-OHTHC and 11-nor-9-carboxy-THC-delta9-tetrahydrocannabinol or THC-COOH) but it also has over 100 minor metabolites [40]. The 11-OH-THC metabolite is psychoactive and is equipotent to THC in terms of psychoactive effects; THC-COOH is not psychotropic and has antiinflammatory and analgesic properties [41, 42]. As mentioned earlier, CBD and CBG affect emesis. CBD is not psychotropic, has little affinity for the $\mathrm{CB} 1 / \mathrm{CB} 2$ receptors, and appears to be a partial agnostic at the serotonin receptors [43]. CBD enhances the expression of the CB1 receptors in the hypothalamus, plus it amplifies the hypothermic effects of THC [44]. In preclinical studies, toxininduced vomiting treated with CBD showed a biphasic response, that is, low doses of CBD had an antiemetic effect while higher doses had a proemetic effect [37, 45]. CBG is not psychotropic and acts as an antagonist at both $\mathrm{CB} 1$ and serotonin receptors [46]. This antagonism might theoretically reverse the antiemetic effects of low doses of $\mathrm{CBD}$ at the serotonin receptor [38]. Thus, it is possible that the severe nausea and intractable vomiting of $\mathrm{CHS}$ might be due to the combined proemetic effects of highdose $\mathrm{CBD}$ coupled with $\mathrm{CBG}$ 's antagonism at the serotonin receptors [13].

Gastric motility and gastroparesis must be discussed in the context of CHS. The enteric nervous system contains CB1 receptors, which, when activated, can inhibit GI motility by inhibiting the release of those transmitters that cause stomach contractions [47]. This effect causes delayed gastric emptying and continues to inhibit transit through the small intestine. The effects are similar to gastroparesis and, thus, CHS may be caused by a functional gastroparesis. The GI effects of cannabinoids are mediated mainly via the CB1 receptor, which can inhibit gastric acid secretion, lower esophageal sphincter relaxation, and alter intestinal motility, cause visceral pain, and produce inflammation [27, 48]. Activating CB1 receptors reduces gastric motility, resulting in delayed gastric emptying in murine $[49,50]$ and human studies $[51,52]$. The delay in gastric emptying seems as if it would be promote emesis [53], yet this delay often occurs with the antiemetic benefits of THC, possibly because those antiemetic effects override the effects of delayed intestinal motility [13]. This applies not just to botanical marijuana; dronabinol (delta-9-tetrahydrocannabinol) slows gastric emptying and decreases colonic tone as well [54].

Chronic or excessive use of cannabinoids may also stimulate the hypothalamic-pituitary-adrenal (HPA) axis and the sympathetic nervous system in addition to disrupting the endocannabinoid system. The endocannabinoid system plays a role in allostasis of the autonomic nervous system following episodes of stress [55]. The HPA axis is the main neuroendocrine system activated by the body when confronting stress [56]. In a healthy individual, the stress response results in the release of corticotrophin-releasing hormone from the hypothalamus into the capillaries and going to the pituitary gland. This causes the pituitary gland to release adrenocorticotropic hormone into the blood stream, which activates the adrenal cortex and leads to the production of corticosteroids [57]. The HPA axis and the sympathetic nervous system must balance their activities in response to stressors. While stress response is vital to survival, prolonged stress increases the allostatic load and can have adverse effects on health $[58,59]$. Interestingly, endocannabinoids play a role in allostasis, that is, they promote the recovery from stress and help to reestablish homeostasis of neurotransmitters, neurohormones, and neuropeptides [60]. This may explain the role of marijuana as a stress reliever.

Based on case reports in the literature, a delay usually occurs between the onset of regular marijuana use and the development of CHS; one case series found the average duration of regular marijuana use before $\mathrm{CHS}$ developed was $16.3 \pm 3.4$ years [61]. In the CHS population, prior daily marijuana use is typical, and some patients report heavy use (multiple times per day, every day). Thus, it has been assumed that CHS only occurs after prolonged exposure to cannabinoids, but one case study $(n=1)$ shows that a single acute intravenous (IV) injection of a crude marijuana extract resulted in emesis [62]. Moreover, acute oral administration of dronabinol can result in abdominal pain, diarrhea, cramps, nausea, and vomiting in $3-30 \%$ of subjects [63-66], but it is not clear if this is true CHS. Acute THC administration may produce a mild form of emesis in some patients, but it appears that chronic THC exposure is required for episodic hyperemesis.

Finally, there have been anecdotal reports that changing the variety or strain of botanical marijuana can mitigate or even alleviate $\mathrm{CHS}$. It has been suggested that $\mathrm{CHS}$ DOI: $10.1159 / 000494992$
Pergolizzi Jr./LeQuang/Bisney 
may - in whole or in part - be the result of pesticides, toxins, or other substances accumulated on the plants during growth and harvest [67]. Chemical residues on the plant can transfer to mainstream smoke with up to 60 or $70 \%$ inhaled via unfiltered glass pipes [68]. Cannabis concentrates, made from leftover leaves and other waste products from the plant, are sold to "dab" onto cannabis for smoking; these dabbed-on cannabis extracts may contain 10 times the pesticides of the buds $[67,69,70]$. While pesticides are an unlikely explanation for CHS, they may be a contributing factor to symptoms.

\section{Incidence and Prevalence}

While clinicians and most regular marijuana users regard CHS as a rare condition - if they have heard of it at all - the literature suggests otherwise. Many cases of CHS are likely misdiagnosed or not medically treated at all. In a study in Spain, a questionnaire was sent out to all patients over 18 years of age who attended a single outpatient marijuana rehabilitation center in 2014; of the 22 respondents, $18.2 \%$ reported symptoms suggestive of CHS [71]. However, reliable data on the incidence and prevalence of CHS are not known. A survey was conducted in a convenience sample of 155 patients between the ages of 18 and 49 years who admitted to smoking marijuana at least 20 times per month; the survey was distributed to qualifying patients who presented at an economically and ethnically diverse urban public hospital. Of this patient population, $32.9 \%$ (95\% confidence interval, range $24.5-40.3 \%$ ) were considered to have met criteria for CHS (chronic cannabis use, episodes of sometimes severe nausea and vomiting, symptomatic relief from hot showers) [72]. If these results are applied to the general population of regular marijuana users in the US, it is possible that 2.75 million Americans (range 2.13-3.38 million) suffer from CHS [72]. It is likely many are not even aware that their symptoms relate to their cannabinoid use.

A 2-year multicenter epidemiology study in Canada reviewed medical records to find patients aged $18-55$ who presented within a 2 -year period at a hospital with a complaint of vomiting, cyclic vomiting, or with a discharge diagnosis of vomiting. Investigators identified 494 cases, $64 \%$ females, mean age $31( \pm 11)$ years, of whom $19.4 \%$ had notations in their charts that they used marijuana, and in this population, $10.4 \%$ reported using marijuana $>3$ times per week. Of this patient population of frequent marijuana users, $43 \%$ had multiple visits to the ED for the same symptoms (nausea and vomiting) [73]. Many of these patients were treated with rehydration (92\%), anti- emetics (89\%), opioids (27\%), underwent some type of imaging procedure (19\%), were referred to gastroenterology for further examination (8\%), or were admitted to the hospital (8\%) [73]. This suggests that CHS is often overlooked as a possible diagnosis and draws attention to the fact that many CHS patients undergo many unnecessary tests, imaging procedures, and even interventions prior to getting an accurate diagnosis.

With the liberalization of marijuana laws since 2009, investigators retrospectively evaluated 2,574 ED visits in Colorado and identified 36 patients diagnosed with cyclic vomiting; this occurred in 128 visits. Episodes of cyclic vomiting nearly doubled in prevalence, increasing from 41 per 113,262 ED visits/year to 87 per 125,095 ED visits per year after marijuana laws were liberalized [74].

\section{Diagnosis}

The diagnostic criteria for CHS were first presented by Simonetto et al. [75] in 2012 as part of a large case series $(n=98)$ at a single tertiary care center. The essential prerequisite for a CHS diagnosis is long-term use of cannabinoids (synthetic, botanical, edibles, prescription "medical marijuana"). Major features for the diagnosis are severe and cyclic episodes of nausea and vomiting that are relieved with hot showers or baths and resolve with cannabis discontinuation. Abdominal pain is another major feature. Supportive criteria for the diagnosis include young age ( $<50$ years), an unintentional weight loss of $>5 \mathrm{~kg}$, a tendency to experience symptoms in the morning, normal bowel habits, and negative results from laboratory, radiographic, and endoscopic tests [75]. Hot showers, in particular, are an important diagnostic criterion because they provide relief from no other CVS. While most CHS patients report heavy marijuana use on a daily basis, the literature confirms CHS may also occur with less frequent (even once-weekly) use.

Since there are no laboratory or radiographic examinations that can be used to diagnose CHS, CHS should be diagnosed based on symptoms and patient behaviors. See Figure 1 for the triad of key features of CHS. In some cases, CHS is a diagnosis of exclusion after other hyperemetic conditions (such as hyperemesis gravidarum, psychogenic vomiting [PV], or CVS) are ruled out.

There are some diagnostic challenges when treating patients with putative CHS. Despite liberalized marijuana laws and reduced social stigma, many patients are not forthcoming about their marijuana use. In fact, obtaining an accurate patient history in this regard may be the single largest stumbling block to CHS diagnosis [8]. In addition to wanting to conceal their marijuana use, patients may 


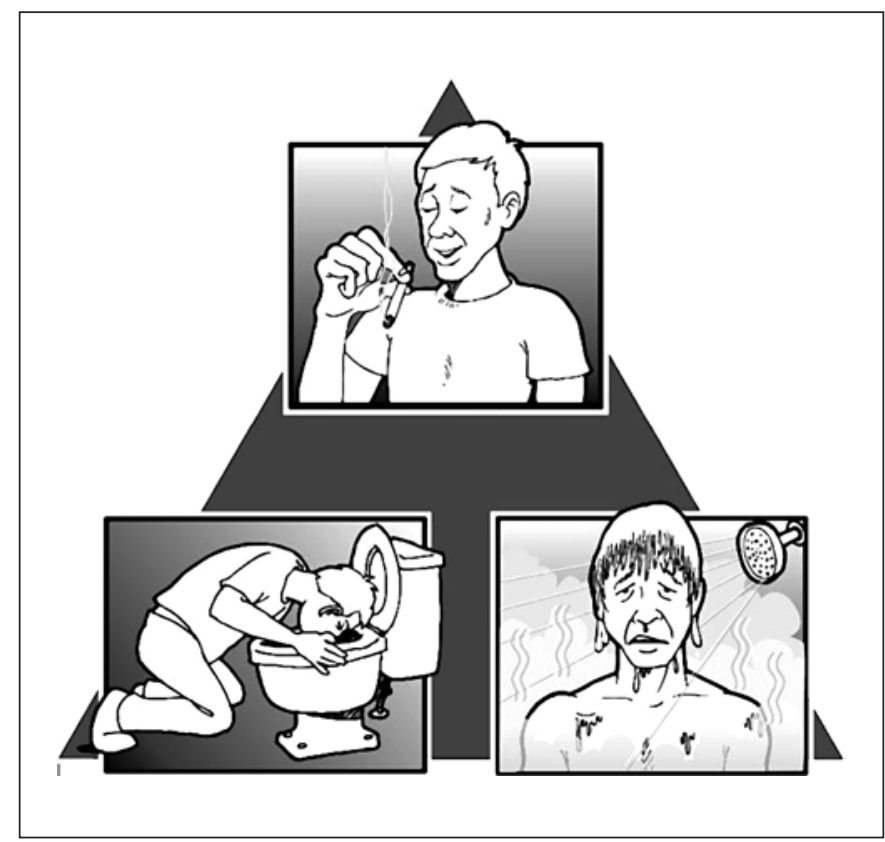

Fig. 1. The triad of features that strongly suggest a CHS diagnosis: regular (and often heavy) marijuana use over a prolonged period of time, episodes of nausea and intractable vomiting that may last hours or days and do not respond to conventional antiemetic therapy, and symptomatic relief from very hot showers or baths.

not associate their symptoms with marijuana consumption and may believe quite firmly that marijuana is "harmless" and, if anything, antiemetic. Urinalysis for cannabinoids is a useful and relatively straightforward test to help with the diagnosis, and few substances other than THC metabolites cause a positive result. The literature reports on one case study where a false-positive in a urine assay was obtained in a pediatric patient treated with pantoprazole [76]. Other potential causes of false-positive results on urine tests for THC include foods that contain hemp, second-hand marijuana smoke, certain NSAIDs, and efavirenz (antiretroviral medication) [77-79].

Most CHS patients have a long history of regular marijuana consumption; the authors know of no cases in which a person first trying marijuana develops CHS. In a systematic review of CHS patients, 179 patients, $25.1 \%$ reported that they used cannabis for $\leq 1$ year, $36.3 \%$ for $2-5$ years, $16.8 \%$ for $6-10$ years, and $21.8 \%$ for $\geq 11$ years. In this same study, frequency of cannabis use $(n=211)$ was reported as: $23.7 \%$ used more than once a day, $47.9 \%$ used daily, $19.4 \%$ used weekly, $2.4 \%$ used less than once a week, and $6.6 \%$ did not specify [80]. Just as patients may not disclose their marijuana use, others may admit to "occasional" marijuana use, but downplay its duration or frequency.
CHS is a recurrent disorder characterized by episodes and symptom-free intervals. Vomiting episodes may last for a few hours $(<12 \mathrm{~h})$ to 7 days [15]. The vomiting phase typically lasts 1-2 days [1]. Between hyperemetic episodes, patients are usually symptom free. Since numerous conditions may cause vomiting, diagnosis is inherently challenging. The fact that CHS is not well known among clinicians can further delay diagnosis, particularly in light of other better-known vomiting syndromes.

\section{Differentiating Cyclic Vomiting, PV, and CHS}

CVS may have known physical causes or be of unknown etiology. PV has been associated with bulimia, anorexia nervosa, and other eating disorders; diagnosis is complicated in that many PV patients use illicit substances, including marijuana, to manage or cope with their symptoms [81]. CVS is a distinct clinical entity, of which hyperemesis gravidarum, associated by metabolic disruptions during pregnancy, is a well-known example. Hyperemesis gravidarum differs from typical morning sickness in that it is more severe and frequently requires medical intervention to rehydrate the mother. CVS was originally thought to be predominantly a pediatric illness [82] and, in children, CVS may be associated with autonomic dysfunction. Abnormal levels of adrenocorticotropic and antidiuretic hormones have been hypothesized [83, 84]. However, pediatric CVS may also be idiopathic. An association between CVS and migraine headaches has also been explored $[85,86]$. In fact, a familial or patient history of migraine supports a CVS diagnosis [87]. Diagnostic criteria have changed to differentiate CVS from CHS, as they are today recognized to be distinct and different clinical syndromes with different etiologies [88]. In addition to migraine headaches, CVS has been associated with psychiatric disorders, gastroesophageal reflux, irritable bowel syndrome, gallbladder disorders, and insulin-dependent diabetes type II, while CHS is associated with chronic marijuana use. Of course, a CHS patient may also be a migraine patient and a CVS patient may smoke marijuana.

CVS of all types (CHS, CVS, PV) exhibit five phases: (1) the patient is free of symptoms between episodes - the periods between episodes may last hours or months; (2) a trigger occurs which may cause the patient to transition to the prodromal phase; (3) in the prodromal phase the patient becomes nauseous and is aware of an oncoming episode - this phase may last minutes or hours; (4) the patient experiences repeated episodes of intractable vomiting, which can go on for hours or even days; and (5) the recovery phase when vomiting stops and the patient is 
able to resume oral intake $[15,89]$. In CHS patients (compared to other cyclic vomiting patients), the prodromal phase can be extremely long - even lasting for years before the patient experiences hyperemesis and months between episodes. The vomiting phase often resolves in $48 \mathrm{~h}$ but can last for days [2]. Other signs and symptoms of CHS include anorexia, retching, increased salivation, stomach pain, cramps, headache, listlessness, pallor, photophobia, phonophobia, and malaise [16]. CHS is predicated on a long history of regular marijuana use, but this may not suffice to distinguish it from CVS, in that $53 \%$ of CVS patients in one study reported having used marijuana [90] and many patients are reticent to discuss their substance use at all.

Since vomiting is a symptom of many conditions, CHS patients often undergo computed tomography scans, magnetic resonance imaging, gastric emptying tests, endoscopy, colonoscopy, even exploratory procedures before a CHS diagnosis is made [91]. It is not unusual for CHS patients to present frequently at the ED and to be hospitalized multiple times per year. This suggests that prompt, accurate diagnosis of CHS may save the healthcare system considerable resources and spare the patient unnecessary testing and procedures.

Patients with CVS may be prescribed a proton pump inhibitor (PPI) to help manage their GI symptoms, but the use of a PPI can result in a false-positive for cannabinoid on a urine test. The PPI pantoprazole provides this information on its labeling, but it is not widely appreciated among clinicians since there are no known published case studies of this in the literature [76]. In a case study of a 13-year-old girl who was treated with pantoprazole for CVS, a urine test was positive for cannabinoids but a subsequent gas chromatography-mass spectrometry test returned negative [76]. The patient had CVS, not CHS, despite a false-positive for marijuana.

CVS patients sometimes use marijuana to help manage their emetic symptoms. In a survey of 514 respondents (437 completed questionnaires) of clinically diagnosed CVS patients, $19 \%$ said they had never used marijuana versus $81 \%$ who had used it in the past or who are currently using it [92]. Many of these patients underwent extensive testing, including $20 \%$ who had a cholecystectomy for symptoms that were later attributed to CVS. On univariate analysis, those patients who used marijuana were significantly more likely to take hot showers to relieve their symptoms $(p<0.0001)$, which suggests that some cases of CVS may actually be CHS, but of those who used marijuana, only $18 \%$ said it controlled their vomiting [92].

Cannabinoid Hyperemesis
Immersing oneself in very hot water relieves vomiting symptoms in CHS patients but has no antiemetic effect on patients with other types of CVS or PV. Thus, learned behavior of bathing in hot water may be used to help diagnose CHS and differentiate it from other CVS [93]. Over $90 \%$ of CHS patients exhibit this behavior [75], which is sometimes described as compulsive. A case study of a 47-year-old man admitted to a hospital in New York for intractable vomiting found he was difficult to treat because he remained in a hot shower all day even in the hospital, taking only two 15-min breaks over the course of a day. The patient found that hot water relieved his symptoms better than anything else. After 3 days in the hospital (and no marijuana use), his symptoms resolved [94]. It should be noted that in the case of CHS, compulsive showering in hot water is not an anxiety disorder but rather a learned behavior that the patient develops to relieve symptoms [94]. Similar to hot water, capsaicin provides symptomatic relief of CHS [95-97] but not other vomiting disorders. Topical capsaicin has been advocated for use as a diagnostic tool for CHS to differentiate it from other vomiting syndromes [36].

A diagnosis of CHS is confirmed when all symptoms resolve for a long period of time ( $\sim 12$ months) with the cessation of marijuana [15]. Patients who stop using marijuana but continue to experience cyclic vomiting are more likely to have CVS. It is typical that CHS symptoms resolve in a matter of days once marijuana is stopped; in some case reports, symptoms resolved in hours. Some important questions for patients to better and more rapidly diagnose CHS are shown in Table 1.

Clinicians may find that discussing marijuana use is a very sensitive topic for some patients. Reticent patients might be told that cannabis may be associated with their condition and that this information will be kept confidential between patient and provider. When discussing marijuana with the patient, the clinician should try to determine when the patient first used marijuana, how frequently it is used, the quantities, and how it is used (smoked, in edibles, "vaped" and so on). The clinician should ascertain whether the cannabinoids are botanical, synthetic, or both, although CHS can occur with cannabinoids in any form. Clinicians also should ask about "dabbing" or whether the marijuana is treated with potent THC extracts and the use of concentrates such as hash oil, "honey oil," wax, "budder," and "shatter," all of which have high THC concentrations. Then, the clinician should try to establish a timeline as to when cannabinoid use first began and when the patient first noticed symptoms of hyperemesis. If the time lag between onset of can-

Med Cannabis Cannabinoids 2018;1:73-95 DOI: $10.1159 / 000494992$ 
Table 1. Diagnosis treatment algorithm aimed at decreasing the need for procedures, tests, scans, and delays in differentiation of CHS from other vomiting syndromes

\begin{tabular}{|c|c|c|}
\hline Question & Answer & Comments \\
\hline $\begin{array}{l}\text { Do you use marijuana or } \\
\text { synthetic marijuana products } \\
\text { regularly? }\end{array}$ & $\begin{array}{l}\text { Typically, patients have used these products } \\
\text { regularly for many years; it is possible for } \\
\text { patients to develop CHS with marijuana use of } \\
\text { a year }\end{array}$ & $\begin{array}{l}\text { Many patients are reticent to disclose this, } \\
\text { particularly if they have legal problems or live in } \\
\text { an area where marijuana is strictly prohibited; a } \\
\text { urine drug test may be helpful }\end{array}$ \\
\hline $\begin{array}{l}\text { Does heat or hot water relieve } \\
\text { your symptoms? }\end{array}$ & $\begin{array}{l}\text { Most patients discover hot showers provide } \\
\text { relief and take them compulsively }\end{array}$ & $\begin{array}{l}\text { Topical capsaicin may be used to promote } \\
\text { warmth; if patient's symptoms resolve with } \\
\text { capsaicin, CHS is likely }\end{array}$ \\
\hline $\begin{array}{l}\text { Have you had this condition } \\
\text { before? }\end{array}$ & $\begin{array}{l}\text { Many patients have a history of episodes of } \\
\text { intractable vomiting followed by asymptomatic } \\
\text { periods; it is not unusual for CHS patients to } \\
\text { have multiple ED visits and hospitalizations } \\
\text { each year }\end{array}$ & $\begin{array}{l}\text { Many patients have been misdiagnosed but will } \\
\text { report that they have had the same symptoms } \\
\text { over and over, often for more than a year }\end{array}$ \\
\hline $\begin{array}{l}\text { Do the typical antinausea } \\
\text { drugs like ondansetron help } \\
\text { you? }\end{array}$ & $\begin{array}{l}\text { Typical antiemetics are generally ineffective } \\
\text { against CHS }\end{array}$ & $\begin{array}{l}\text { Typical antiemetics can help CVS, hyperemesis } \\
\text { gravidarum and other conditions but are not } \\
\text { usually effective in CHS }\end{array}$ \\
\hline $\begin{array}{l}\text { Are you willing to stop using } \\
\text { marijuana to see if your } \\
\text { symptoms stop? }\end{array}$ & $\begin{array}{l}\text { Many chronic marijuana users are resistant to } \\
\text { the notion that marijuana has anything to do } \\
\text { with their symptoms; some see marijuana as an } \\
\text { antiemetic and a benign drug }\end{array}$ & $\begin{array}{l}\text { Resistance to stopping marijuana use even for a } \\
\text { short time to allay distressing symptoms may } \\
\text { confirm that the patient is a chronic and likely } \\
\text { heavy user and could be suffering from CHS }\end{array}$ \\
\hline
\end{tabular}

nabinoid use and symptoms is $>1$ year, this supports a diagnosis of CHS [98]. The clinician should also ask if the patient had discontinued marijuana use for any appreciable time period; if the patient was asymptomatic during such periods of abstinence, this further supports CHS as the diagnosis [98].

\section{Treatment}

Unlike CVS and PV, CHS is not usually relieved by antiemetic pharmacological therapy, but many patients exhibit the learned behavior of taking hot showers and baths for temporary symptomatic relief. In some cases, IV haloperidol or lorazepam (for anxiety) may provide relief for the CHS patient $[14,89]$. In the literature, there is one case report of "atypical CHS" in which the patient found relief from cold showers or other ways to chill himself (use of a fan, lying on cold marble floor) but this case must be viewed as an outlier [99]. Treatment guidelines published by the San Diego Emergency Medicine Oversight
Commission recommend supportive care (rehydration), patient education, and counsel to stop the use of cannabinoids [100]. Topical capsaicin can be used to provide symptomatic relief but symptoms typically resolve in a day or two without cannabinoid use regardless of treatment. Benzodiazepines and opioids, although sometimes prescribed, have very limited effectiveness for this condition [100].

\section{Supportive Care}

In the acute setting, volume resuscitation is urgently required for many CHS patients who may arrive dehydrated and hypovolemic. Electrolyte replacement is appropriate to correct any electrolyte imbalances that may have occurred with prolonged vomiting. While patients benefit from rehydration and other forms of supportive care, the only effective treatment for CHS is marijuana cessation. Conventional antiemetics are not contraindicated but are generally ineffective likely because of the atypical mechanisms behind CHS.
Pergolizzi Jr./LeQuang/Bisney 


\section{Hot Showers}

For CHS patients, nausea and vomiting may be relieved in a matter of minutes upon immersion in hot water [1]. Compulsive bathing in hot water is pathognomonic for CHS for reasons that remain to be elucidated. Three older hypotheses appear in the literature. The first is that cannabinoids contain psychoactive components which are hypothermic, and chronic users seek warmth to better regulate their core body temperature. Second, the body's CB1 receptors are located in proximity to the body's thermoregulation system in the hypothalamus, and warm water helps regulate body temperature [19, 101]. Third, it may be that warm water helps direct blood flow to the periphery and skin, away from the gut [102]. The recent research implicating TRPV1 ion channels in CHS offers a new hypothesis in that the TRPV1 ion channels open at very warm temperatures $\left(>43^{\circ} \mathrm{C}\right)$ [103] or specific binding with capsaicin $[96,104]$. Opening the TRPV1 ion channel may produce antiemetic benefits. Thus, as long as a CHS patient can expose enteric TRPV1 channels to heat, these channels will help fight emesis.

Most CHS patients discover the symptomatic relief of hot showers on their own and use this method to control symptoms [1]. In a case study from Texas, a 27-year-old male patient with CHS reported he found relief in hot showers but over time, he became refractory to the hot water and ended up having to visit the ED [105].

\section{Topical Capsaicin}

In a retrospective chart review of 13 patients treated for CHS at one of two centers, $100 \%$ of patients experienced relief when topical capsaicin was administered to help control symptoms of vomiting [96]. A thin layer of topical capsaicin cream was applied to the abdominal region, chest, or back. All patients reported relief with the first application. Only one CHS patient returned to the ED within 3 days after receiving topical capsaicin; capsaicin was administered again, and the patient reported rapid relief and was discharged without further treatment [96]. In a study of the treatment of neuropathic pain with topical capsaicin, the most common adverse effect was a burning sensation upon application, localized erythema, and nonproductive cough [106]. It is likely that topical capsaicin used for CHS treatment would have similar adverse effects.

In a case series treating 2 CHS patients (one 17-yearold female, one 20 -year-old male), both patients were regular marijuana users who reported to the ED with abdominal pain, nausea, and intractable vomiting; both were treated with antiemetic therapy and discharged, only to return within the week with the same symptoms. On the second visit, CHS was diagnosed and the patients were treated with capsaicin cream $0.025 \%$ applied in a layer approximately $1 \mathrm{~mm}$ thick on the abdomen. In both cases, topical capsaicin provided symptomatic relief in about $30 \mathrm{~min}$. Both patients reported a burning sensation where the capsaicin was applied but were satisfied with the results [97].

The mechanism of action of topical capsaicin likely involves TRPV1 receptors. When they are activated by capsaicin (or heat), they modulate tachykinins, somatostatin, pituitary adenylate-cyclase (which, in turn, activates the polypeptide system), and calcitonin gene-related peptides and affect the systems involved in histamine, choline, and serotonin transmission [107]. In other words, topical capsaicin opens the TRPV1 channels, which has an antiemetic effect.

Capsaicin is inexpensive, readily available over the counter, and associated with few adverse events. It is available in $0.025,0.075$, and $0.1 \%$ concentrations as a topical cream (not all concentrations are available in all locations), and there is also an $8 \%$ topical capsaicin patch [107]. Topical capsaicin is absorbed into the epidermal and dermal layers for a prolonged period, even $24 \mathrm{~h}$ after it has been removed from the skin [108]. It is metabolized by the CYPP450 enzyme system [109] and has a half-life of $1.64 \mathrm{~h} \mathrm{[110].}$

\section{Haloperidol}

Haloperidol is a familiar but unconventional antiemetic that may benefit CHS patients, likely because it blocks the brain's postsynaptic dopamine receptors [111, 112]. When dopamine receptors are blocked, the blockade reduces the effect of dopamine on the dopamine- 2 receptors in the vomiting center [96]. Haloperidol may further relieve nausea and vomiting by indirect activity at the CB1 receptors $[111,113]$. In a case study of a 27 -yearold man who suffered repeated episodes of gastric pain, up to 20 vomiting episodes per day, coupled with severe nausea, multiple diagnostic tests were performed before a CHS diagnosis could be made. During his last hospitalization he was given conventional antiemetic therapy but his symptoms persisted for 2 more days. He consented to IV haloperidol $1 \mathrm{mg}$ which relieved his symptoms and produced no adverse effects; he subsequently received two more IV doses of $2 \mathrm{mg}$ before he was discharged [114]. An 18-year-old patient diagnosed with CHS refused to stop using marijuana and was treated in-clinic with haloperidol followed by outpatient $5 \mathrm{mg}$ haloperidol which relieved her symptoms of nausea and vomiting. No 
adverse effects were reported. The patient discontinued haloperidol on her own after 3 weeks and was subsequently lost to follow-up [113].

An important clinical concern is that haloperidol is associated with potentially serious adverse events which may occur with the first dose, such as extrapyramidal reactions, e.g. dystonia, and neuroleptic malignant syndrome. Since most CHS patients are young and otherwise healthy, haloperidol may not pose excessive risk. It has a long history of use as an antiemetic in oncology and general surgery. In a case series of 4 CHS patients in emergency care, IV haloperidol $5 \mathrm{mg}$ resolved vomiting in 1 or

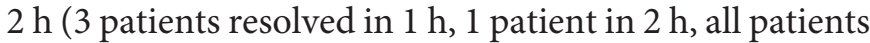
received one dose), while other conventional treatments such as ondansetron were ineffective [115]. Thus, in this case series, all patients achieved significant symptomatic relief from hyperemesis within 1 or $2 \mathrm{~h}$ with IV haloperidol, could be discharged within $8 \mathrm{~h}$ of treatment, did not require hospitalization, and reported symptomatic relief that did not require a second dose [115].

\section{Lorazepam}

In some cases, lorazepam may be helpful to counteract the anxiety suffered by the patient, but lorazepam as treatment for CHS is generally not effective [116].

\section{Beta-Blockers}

A recent, published in 2016, case report describes the first use in the literature of propranolol to treat $\mathrm{CHS}$ [117]. A 37-year-old man in profound distress suffering hyperemesis presents at the ED, stating he had similar experiences in the past which could be relieved with hot showers, but this time hot water provided no relief. The patient admitted he had smoked marijuana on a daily basis for the past 20 years. In the ED, the physician treated him with IV propranolol $1 \mathrm{mg}$ as this had been effective in cases of CVS. The patient continued to experience symptoms and received a second dose of IV propranolol $1 \mathrm{mg}$ an hour later, whereupon his symptoms stopped completely. The patient could be discharged $4 \mathrm{~h}$ later and was counseled to stop smoking marijuana [118]. Propranolol is a nonspecific, lipophilic beta-1/beta-2-blocker that has been used to treat CVS, particularly in pediatric patients [119]. Its use in CHS has to date been very limited.

\section{Patient Education}

Patient education is an important part of treatment, as many CHS patients remain unconvinced that marijuana causes hyperemesis because in popular culture (and even among healthcare professionals) its antiemetic properties are much better known than CHS. Moreover, there is a general popular belief that marijuana is "natural" and would not be associated with severe adverse effects. Patients may be resistant to the notion that their symptoms are related to cannabis use. CHS is not well known, even among medical professionals, which exacerbates the disbelief some patients experience upon learning that marijuana may have side effects.

\section{Marijuana Cessation}

Hospital admission in and of itself can serve to resolve $\mathrm{CHS}$ in that patients abstain from marijuana during the time they are inpatients. Since marijuana resumption will cause CHS to return, patient education is important in order to prevent recurrence. If patients suffer repeatedly from CHS despite their being informed of the connection between marijuana and CHS, it may be appropriate to refer these patients to addiction specialists, substance use counselors, or other rehabilitation programs. Marijuana cessation relieves CHS, sometimes in a matter of hours or a couple of days. In a case study of a 26-year-old woman who suffered from CHS for years and had been using marijuana nonmedically for 11 years, symptoms resolved in the relatively long period of 3 weeks of cannabis abstinence [117].

Acute treatment of CHS is supportive care and patient education; the only effective long-term approach to CHS is marijuana cessation. In fact, the authors know of no reports in the literature of a CHS patient who continued to experience symptoms after marijuana was discontinued. However, not all patients are adherent to a cessation plan. In a retrospective case series from the UK, $10 \mathrm{CHS}$ patients were followed for a median of 9.5 months (range 1-20 months) following counseling to stop using marijuana to avoid symptoms. Seven of the patients abstained from marijuana during this time and had no further episodes; 3 patients resumed their use of marijuana and had further episodes [120].

\section{Special Populations}

\section{Pregnant Women}

CHS may be confused with hyperemesis gravidarum, so an accurate diagnosis is important to avoid costly and time-consuming diagnostic steps and to avoid prolonging the patient's suffering as these two conditions respond to different treatments [121]. Pregnant women may not be forthcoming about their marijuana use, which can complicate diagnosis [121]. Maternal cannabinoid use alone does not necessarily mean that hyperemesis is CHS.
Pergolizzi Jr./LeQuang/Bisney 
While the use of marijuana during pregnancy has not been thoroughly studied, it is associated with risk, although many pregnant women persist in marijuana use [122]. In a retrospective study from Hawaii, 4,735 respondents were asked to report their marijuana use during pregnancy, in the month before pregnancy, and nausea during pregnancy [123]. Data were then weighted to represent all pregnancies that resulted in live births in Hawaii from 2009 to 2011 . Of these women, 6.0\% reported that they had used marijuana in the month before pregnancy, and $2.6 \%$ said that they used marijuana during their pregnancy. Severe nausea was reported by $21.2 \%$ of respondents, and those reporting severe nausea were more likely to have used marijuana during pregnancy (3.7 vs. 2.3\%) and more likely to have used marijuana before pregnancy (7.0 vs. $5.5 \%)$. However, no statistically significant association between marijuana use before or during pregnancy and nausea could be achieved $(p=0.134)$ [123].

The risks associated with prenatal exposure to THC remain to be elucidated, but in light of today's high-potency cannabinoids, there is justifiable concern. The role of marijuana as an antiemetic may encourage some women to use it during pregnancy, but such use is not clinically reasonable because the risks to human neurodevelopment remain unknown. In those states in the US that allow for medical marijuana, none make specific recommendations or warnings related to pregnancy and none describe any potential risks to a fetus [122]. The American College of Obstetricians and Gynecologists have issued an opinion statement in 2015 and revised in 2017 that discourages physicians from recommending marijuana use during pregnancy, lactation, or in the preconception period [124].

\section{Pediatric Patients}

Since CHS is thought to occur only with long-term marijuana use, a CHS diagnosis is often ruled out for adolescents and children. However, case studies demonstrate that adolescents are susceptible to CHS. The youngest age for a CHS case in the literature found by the authors is 15 years [125]. In a report on a 16-year-old CHS patient, she reported that she used marijuana herself but had been exposed prior to that to secondhand smoke for many years, as her family used marijuana [125].

\section{Dual Diagnosis}

The serum levels of psychiatric drugs may be reduced in patients suffering from CHS or other vomiting syndrome. A vicious cycle can occur in which $\mathrm{CHS}$ patients taking psychiatric medications suffer nausea and vomit- ing, increase their use of marijuana to manage those symptoms, and exacerbate their mental health condition. For patients on psychiatric pharmacological regimens, CHS can have a destabilizing effect on the patient [126]. Furthermore, the distressing and relentless symptoms of CHS can worsen the patient's mental health as well. A description of a patient with CHS in Australia revealed that her CHS symptoms exacerbated her anxiety disorder, and she presented to the ED with anxiety plus vomiting [127].

\section{Clinical Considerations}

Marijuana is widely thought to be a powerful antiemetic. Oncology patients may be advised to use cannabinoids to relieve chemotherapy-induced nausea and vomiting, only to develop CHS over time. The belief in marijuana as a therapeutic and benign agent is so pervasive among some patients and certain healthcare personnel that they will persist in using cannabinoids, even if they are educated about the role of marijuana as a potential proemetic $[1,13]$. In some case reports in the literature, a few patients rejected the notion that marijuana might in some way be the cause of their symptoms and refused to give it up even to see if it might relieve their symptoms [1]. The literature reports on global clinical experience with CHS to date in the form of case studies, case reports, and case series. Large retrospective or prospective studies are few. While case reports are not the strongest form of evidence, the range of case reports in the literature over the past years presents a coherent picture of the condition, its diagnosis, and treatment.

\section{Case Series and Case Studies}

The first description of CHS as a distinct clinical disorder occurred in a case series published in 2004 by Allen et al. [1] from Australia. A total of 19 patients were identified for the case series, of whom 10 were excluded (failure to consent, etc.), and one patient with PV was added. Compulsive hot bathing was observed in $9 / 10$ patients. Seven patients stopped marijuana used and all symptoms resolved; 3 continued to use marijuana and continued to suffer CHS [1]. The largest case series presented to date $(n=98)$ comes from Simonetto et al. In this population, no individual was over 50 years of age, and for the individuals for whom data were available, $68 \%$ reported that they had used cannabinoids for at least 2 years prior to development of symptoms, and $95 \%$ of those who reported frequency of use said they used cannabis at least once a week. Abdominal pain occurred in $86 \%$, and $91 \%$ of pa- 
tients said that hot showers relieved their symptoms. Only 10/98 patients were followed long term, and of those, $70 \%$ discontinued their use of cannabis with $6 / 7$ of this group reporting complete resolution of symptoms [75].

A case series from France reported on 19 cases of CHS from 2012 to 2016, with the majority of patients male, with a mean age of 29.8 years (range $20-48$ years), and all regular cannabis users with an average daily consumption of 10 cigarettes per day (range 2-20). The onset of symptoms was reported in 13 of those cases at a median of 9 years (range 3-25 years). In the limited subset of cases where data were available, it appeared that it took a mean of 2.6 years (range 1 day to 9 years) to get a CHS diagnosis. All patients reported intractable vomiting for $24-48$ $h$, and all patients suffered abdominal pain; many experienced weight loss as well. Hot showers for symptomatic relief were reported by 17/19 patients [128]. Marijuana cessation was recommended to all patients, but there was no long-term follow-up.

A case series from Spain from 2012 to 2016 involved 6 patients ( 5 men) with an average age of 28.3 years who, on average, began to use marijuana at age 16 . In this series, the mean amount of cannabis smoked per day was 7.5 cigarettes (range 1-12) for at least 1 year prior to the first episode of vomiting. The average length of time between the onset of symptoms and a CHS diagnosis was 6.1 years (range 1-10 years) and patients visited the ED at average of 10 times before diagnosis was made. All patients found relief in hot showers and all were described as "uncooperative" with a CHS diagnosis. Upon being hospitalized, $100 \%$ of patients had complete resolution of all symptoms an average of 3.6 days after discontinuation of marijuana (range 2-5 days). Five of the 6 patients were monitored by substance dependency units, and 3 of them abstained from cannabinoids; one discontinued marijuana and then relapsed and had another episode of acute intractable vomiting; one patient reduced marijuana use from 3 to one cigarette per day and had no further symptoms. One patient was lost to follow-up [129]. In this case series, the investigators noted that this latter patient - who continued to use cannabis - had the greatest number of acute episodes of CHS [129]. Thus, severe symptoms may not be sufficient to compel an individual to discontinue marijuana or cannabis may have an adverse effect on the individual's ability to make sound decisions [129].

A case series from 2010 in the United States described 4 individuals with a history of cannabinoid use who developed episodes of abdominal pain, nausea, and vomit- ing which could be relieved, in all cases, by bathing in hot water [102]. In all 4 cases, CHS was diagnosed, and patients were counseled to avoid cannabis in the future. Three out of 4 patients resumed marijuana use and presented at the hospital again. One of the patients, a 27-yearold man, said he understood the cause of his symptoms but was "unable" to stop smoking marijuana. Another patient in the series, a 31-year-old man, discontinued marijuana for a short time, then resumed and periodically visits the ED to manage symptoms [102]. The third patient (20-year-old man) stopped marijuana use for 2 months after CHS diagnosis, but resumed again, which resulted in another hospitalization [102].

In a retrospective review of CHS patients admitted to a single urban ED in France, 7 patients were identified with a mean age of 24.7 years (range 17-39 years); most were men. Five of these 7 patients found relief in hot showers. In this study, patients were offered a referral to an addiction team. Five patients agreed to work with the addiction team and discontinued the use of marijuana, but 2 patients refused and resisted the notion that they should give up marijuana [130]. Patients were not followed long term.

A retrospective case series from the UK reported on 10 cases of CHS which had originally been diagnosed with alternative conditions (4 with CVS, and one each with PV, Ehlers-Danlos syndrome, multiple sclerosis, viral gastroenteritis, functional dyspepsia, and bulimia nervous) [120]. There were 5 men and 5 women included, mean age 27 years (range 19-51 years) with symptoms of abdominal pain, nausea, and hyperemesis refractory to medical therapy. The mean delay to the accurate diagnosis of CHS was $15.2 \pm 10.5$ months with a median of $4 \mathrm{ED}$ admissions (range 0 to 14). All patients had a history of long-term use of cannabis (mean length 42 months, range $15-81.8$ months), and $80 \%$ found relief in taking hot showers. Patients were followed for a median of 9.5 months (range 1-20 months). In this group, 9 patients smoked marijuana for recreation, while the other patient had been prescribed synthetic cannabinoids (nabilone $2 \mathrm{mg}$ twice a day) to treat multiple sclerosis. The approximate consumption of THC per day was a mean of $70.3 \pm 40.8 \mathrm{mg}$. Seventy percent of patients reported symptoms typically began in the morning [120].

A systematic review of 29 cases of CHS in France was reported by Schreck et al. [131] in 2018. As with similar series, they found the patients were typically young (25.8 years) males (65.5\%) who had used cannabinoids daily for several years, found relief in hot showers, and for
Med Cannabis Cannabinoids 2018;1:73-95 DOI: $10.1159 / 000494992$
Pergolizzi Jr./LeQuang/Bisney 
whom antiemetic therapy was ineffective. In this case series, $17.2 \%$ of patients suffered from chronic anxiety. It is not clear if there is a comorbid association between CHS and anxiety or whether the symptoms of CHS are so distressing that patients become anxious.

A case series from the US $(n=8)$ from a single center in 2009 reported patients were an average of $3.24 \pm 4.1$ years old, $5 / 8$ were men, and there was a mean interval of $19.0 \pm 3.7$ years between the onset of cannabis use and symptoms [61]. In this study, $62.5 \%$ were Caucasian, $25 \%$ African-American, and 12.5\% Middle Eastern. Patients had a mean of $7.1 \pm 4.3 \mathrm{ED}$ visits and $3.1 \pm 1.9$ hospitalization for this condition. All patients in this series compulsively took hot showers to control symptoms. Of the 8 patients, 5 discontinued cannabis use upon diagnosis and 3 did not. Four of the 5 who discontinued cannabis saw complete resolution of symptoms although in one case, symptoms returned when the patient resumed use of cannabis [61].

\section{Case Reports}

The literature contains a wealth of case studies and case reports on patients suffering from CHS; these case reports come from around the world but have striking similarities. A summary of these studies appears in Table $2[6,7,10,19,22,54,94,97,99,101,105,111,113,114$, $116,117,121,126,127,132-173]$.

A few important details emerged from the case studies. CHS tends to affect younger people; the patients reported in Table 2 ranged in age from 15 to 47 years. It has been suggested that this is due to the fact that cannabinoid use is about double in younger people compared to older individuals [135]. The authors found no cases of geriatric CHS ( $\geq 65$ years), but there is no reason evident why geriatric individuals who used marijuana long term would be immune from CHS. Most individuals diagnosed with CHS have long-term marijuana use that precedes symptoms, but the cases series by Simonetto et al. [75] reported that $32 \%$ of patients diagnosed with CHS develop it in their first year of marijuana use and $44 \%$ develop it in the first 5 years. It is not known why the syndrome develops in some, but not all, long-term marijuana users and why symptoms take longer to manifest in some patients than others. Although there were very few case studies involving CHS patients with eating disorders, bulimia might present in such a way that it could be confused with CHS. About $35 \%$ of individuals with some form of substance use disorder have an eating disorder (which typically precedes the substance use disorder) versus $5 \%$ of the general population [174].

Cannabinoid Hyperemesis

\section{Complications Secondary to CHS}

\section{Renal Dysfunction}

CHS has been associated with acute renal failure [1]. Hyperemesis can disturb the patient's electrolyte balance and cause severe dehydration. Oliguria can lead to increased serum creatinine levels and creatinine kinase [166]. A case study from Australia reported a 25-year-old man in renal failure because of dehydration as a result of CHS. He smoked at least $2 \mathrm{~g}$ of marijuana daily for the past 8 years, and hot showers provided relief from his CHS. Persistent vomiting and hot showers caused severe dehydration which was treated in the hospital, causing creatinine levels to drop from their initial values of 3.21 to 1.4 $\mathrm{mg} / \mathrm{dL}$ the next day [137]. Other case reports describe patients in prerenal failure secondary to CHS $[138,175]$.

\section{Low Serum Phosphate Levels}

Low serum phosphate levels $(<2.5 \mathrm{mg} / \mathrm{dL})$ occur in about $5 \%$ of all hospitalized patients [176]. However, serum phosphate levels are not an accurate reflection of the body's phosphate reserves [177]. The main causes of hypophosphatemia are enteric malabsorption or loss, excessive excretion in urine, or redistribution within the body (phosphate moving out of circulation and into cells). Phosphate depletion over long term can be serious and even represent a medical emergency, associated with symptoms such as ataxia, rhabdomyolysis, and decreased myocardial contractility. On the other hand, hypophosphatemia associated with phosphate redistribution is often asymptomatic and resolves spontaneously $[176,178]$. In a retrospective study at the Veterans Affairs Medical Center in San Diego, California, 6 men treated for CHS had hypophosphatemia $(<1-1.3 \mathrm{mg} / \mathrm{dL})$. In 3 patients, serum phosphate levels returned to normal spontaneously within a matter of hours and $4 / 6$ patients exhibited signs of hyperventilation, which has been associated with hypophosphatemia [178]. The hyperventilation in all cases was attributed to a mental health disorder, such as generalized anxiety disorder or posttraumatic stress disorder. After this study, charts were reviewed later in the year, and 5/6 patients had been back to the hospital for CHS, 4 of whom had serum phosphate levels $<2.5 \mathrm{mg} / \mathrm{dL}$. It appears in this study that the patients suffered from respiratory alkalosis likely brought on by anxiety-driven hyperventilation. Since these patients reported using marijuana in part to help manage their anxiety, it may be that some CHS patients present with hypophosphatemia that is caused by phosphate redistribution and resolves spontaneously.

Med Cannabis Cannabinoids 2018;1:73-95 DOI: $10.1159 / 000494992$ 
Table 2. Case reports from a systematic literature search for "cannabinoid hyperemesis" and "cannabis hyperemesis" in May 2018

\begin{tabular}{|c|c|c|c|c|c|c|}
\hline $\begin{array}{l}\text { First author, year } \\
\text { [Ref.] }\end{array}$ & $\begin{array}{l}\text { Age in years, sex, } \\
\text { relevant history }\end{array}$ & Prior reports & Hot showers & $\begin{array}{l}\text { Prior } \\
\text { marijuana use }\end{array}$ & $\begin{array}{l}\text { Diagnosis/ } \\
\text { treatment }\end{array}$ & $\begin{array}{l}\text { Resolution/ } \\
\text { follow-up }\end{array}$ \\
\hline $\begin{array}{l}\text { Alaniz, } 2016 \\
{[121]}\end{array}$ & $\begin{array}{l}28, \mathrm{~F} \text { ( } 3 \text { trimester } \\
\text { pregnant) }\end{array}$ & $\begin{array}{l}\text { Persistent nausea and } \\
\text { vomiting leading to loss of } \\
\text { consciousness }\end{array}$ & Yes & 12 y heavy use & $\begin{array}{l}\text { Hyperemesis gravidarum at } \\
\text { first, then CHS, patient cut } \\
\text { back on marijuana use to } 1 / \mathrm{d}\end{array}$ & Pt lost to follow-up \\
\hline $\begin{array}{l}\text { Bagdur, } 2012 \\
{[105]}\end{array}$ & $27, \mathrm{M}$ & Multiple episodes & $\begin{array}{l}\text { Yes but eventually } \\
\text { they provided little } \\
\text { to no relief }\end{array}$ & $6 y$ & CHS, marijuana cessation & $\begin{array}{l}\text { Symptoms resolved in } 48 \mathrm{~h} \\
\text { after stopping marijuana }\end{array}$ \\
\hline Baron, 2011 [138] & $28, \mathrm{M}$ & $12 \mathrm{y}$ & Yes & $14 \mathrm{y}$ & $\begin{array}{l}\text { Prerenal failure secondary to } \\
\text { CHS but pt would not agree to } \\
\text { d/c marijuana }\end{array}$ & $\begin{array}{l}\text { Pt returned to ED with same } \\
\text { symptoms and secondary } \\
\text { renal dysfunction }\end{array}$ \\
\hline Beech, 2015 [132] & $42, \mathrm{~F}$ & Head trauma complications & Yes & $8 \mathrm{y}$ & CHS, marijuana cessation & \\
\hline $\begin{array}{l}\text { Bonnet, } 2016 \\
{[117]}\end{array}$ & $26, \mathrm{~F}$ & $\begin{array}{l}2-3 \text { episodes/wk past } \\
5 \text { y }\end{array}$ & Yes & $11 \mathrm{y}$ & $\begin{array}{l}\text { Misdiagnosed, pt read about } \\
\text { CHS and reported to physician } \\
\text { who confirmed diagnosis }\end{array}$ & $\begin{array}{l}\text { Symptoms resolved in } 3 \mathrm{wk} \\
\text { of cessation, follow-up at } 12 \\
\text { mo found she had not } \\
\text { resumed marijuana use and } \\
\text { had no further symptoms }\end{array}$ \\
\hline $\begin{array}{l}\text { Braver, } 2015 \\
{[134]}\end{array}$ & $\begin{array}{l}34, \mathrm{M}, \\
\text { veteran with } \\
\text { PTSD }\end{array}$ & Persistent vomiting & Yes & $\begin{array}{l}\text { Heavy use, } \\
\text { duration not } \\
\text { quantified }\end{array}$ & $\begin{array}{l}\text { CHS, advised to stop } \\
\text { marijuana }\end{array}$ & $\begin{array}{l}\text { Patient continued marijuana } \\
\text { and returned to ED }\end{array}$ \\
\hline $\begin{array}{l}\text { Braver, } 2015 \\
{[134]}\end{array}$ & $44, \mathrm{M}$ & $\begin{array}{l}\text { Abdominal pain with } \\
\text { recurrent vomiting } 5 \mathrm{y}\end{array}$ & Yes & $30 \mathrm{y}$ & CHS & Symptoms resolved in $9 \mathrm{~h}$ \\
\hline $\begin{array}{l}\text { Brewerton, } 2016 \\
{[133]}\end{array}$ & $22, \mathrm{~F}$ & $\begin{array}{l}\text { Mental health disorders, } \\
\text { binge/purge anorexia, } \\
\text { intractable vomiting }\end{array}$ & Yes & $7 y$ & $\begin{array}{l}\text { CHS, patient became angered } \\
\text { and asked to be discharged }\end{array}$ & Unknown \\
\hline $\begin{array}{l}\text { Camilleri, } 2018 \\
{[54]}\end{array}$ & $51, \mathrm{~F}$ & $\begin{array}{l}\text { Nausea, vomiting, abdominal } \\
\text { pain, prior cholecystectomy } \\
\text { and hysterectomy }\end{array}$ & No & $\begin{array}{l}\text { Yes, duration not } \\
\text { quantified }\end{array}$ & $\begin{array}{l}\text { Common bile duct stone ( } 1 \\
\mathrm{~cm} \text { ) removed which did not } \\
\text { improve symptoms; delayed } \\
\text { gastric emptying; CHS }\end{array}$ & $\begin{array}{l}\text { Pt counseled to stop } \\
\text { cannabis, dietary restrictions, } \\
\text { antiemetic therapy, referral } \\
\text { to mental health provider }\end{array}$ \\
\hline Cha, 2014 [136] & $44, \mathrm{M}$ & $\begin{array}{l}\text { Recurrent, every morning, } \\
\text { duration NR }\end{array}$ & $\begin{array}{l}\text { Yes, suffered burns } \\
\text { from hot water }\end{array}$ & $>20 y$ & CHS & $\begin{array}{l}\text { Follow-up at } 9 \text { y found pt } \\
\text { stopped marijuana use, no } \\
\text { return of symptoms }\end{array}$ \\
\hline $\begin{array}{l}\text { Chang, } 2009 \\
{[101]}\end{array}$ & $\begin{array}{l}25, \mathrm{~F} \text {, bipolar } \\
\text { disorder, obesity }\end{array}$ & $5 \mathrm{y}$ of intermittent episodes & Yes & $\sim 7 \mathrm{y}$ & CHS & $2 \mathrm{~h}$ \\
\hline Cox, 2012 [10] & $28, \mathrm{M}$ & $2 \mathrm{wk}$ & Yes & $1.5 \mathrm{~g} /$ day & $\begin{array}{l}\text { CHS, IV lorazepam } 1 \mathrm{mg} \\
\text { relieved symptoms at once }\end{array}$ & $\begin{array}{l}\text { Pt counseled to stop } \\
\text { marijuana, at } 6 \text { mo follow-up } \\
\text { he had done so, no recurrent } \\
\text { symptoms }\end{array}$ \\
\hline $\begin{array}{l}\text { Desjardins, } 2015 \\
{[135]}\end{array}$ & $17, \mathrm{M}$ & $5 \mathrm{ED}$ visits in last year & Yes & Yes NR & CHS & About $5 \mathrm{~d}$ \\
\hline Enuh, 2013 [94] & $\begin{array}{l}47, \mathrm{M}, \\
\text { diabetes }\end{array}$ & Yes & Yes & $39 \mathrm{y}$ of daily use & CHS & $3 \mathrm{~d}$ \\
\hline $\begin{array}{l}\text { Figueroa-Rivera, } \\
2015 \text { [7] }\end{array}$ & $\begin{array}{l}29, \mathrm{M}, \\
\text { anxiety disorder, } \\
\text { MDD, SUD }\end{array}$ & $\begin{array}{l}\text { Multiple ED visits in past } \\
\text { year }\end{array}$ & Yes & $16 \mathrm{y}$, daily use & $\begin{array}{l}\text { IV lorazepam provided relief; } \\
\text { CHS diagnosed }\end{array}$ & $3 \mathrm{~d}$ \\
\hline Fleig, $2011[6]$ & $\begin{array}{l}28, \mathrm{M}, \\
\text { recently } \\
\text { unemployed }\end{array}$ & $\begin{array}{l}\text { Several days of vomiting } \\
\text { preceded this ED visit }\end{array}$ & Yes & $\begin{array}{l}10 \text { y regular } \\
\text { marijuana use } \\
\text { (also cocaine, } \\
\text { other drugs); with } \\
\text { unemployment } \\
\text { marijuana use } \\
\text { increased to } \\
\text { hourly }\end{array}$ & CHS, referral for detox & $\begin{array}{l}\text { Symptoms resolved quickly } \\
\text { with marijuana cessation but } \\
\text { patient was unsure if he } \\
\text { wanted to forego use of } \\
\text { marijuana }\end{array}$ \\
\hline $\begin{array}{l}\text { Graham, } 2017 \\
\text { [97] }\end{array}$ & $16, \mathrm{~F}$ & $\begin{array}{l}1 \text { wk of vomiting preceded } \\
\text { ED visit }\end{array}$ & NR & $\begin{array}{l}\text { Regular use of } \\
\text { marijuana which } \\
\text { increased to } \\
\text { manage her } \\
\text { nausea and } \\
\text { vomiting }\end{array}$ & $\begin{array}{l}\text { CHS, treated with topical } \\
\text { capsaicin }\end{array}$ & $\begin{array}{l}\text { Symptoms resolved quickly } \\
\text { with capsaicin; patient was } \\
\text { educated about CHS }\end{array}$ \\
\hline
\end{tabular}


Table 2 (continued)

\begin{tabular}{|c|c|c|c|c|c|c|}
\hline $\begin{array}{l}\text { First author, year } \\
\text { [Ref.] }\end{array}$ & $\begin{array}{l}\text { Age in years, sex, } \\
\text { relevant history }\end{array}$ & Prior reports & Hot showers & $\begin{array}{l}\text { Prior } \\
\text { marijuana use }\end{array}$ & $\begin{array}{l}\text { Diagnosis/ } \\
\text { treatment }\end{array}$ & $\begin{array}{l}\text { Resolution/ } \\
\text { follow-up }\end{array}$ \\
\hline $\begin{array}{l}\text { Graham, } 2017 \\
\text { [97] }\end{array}$ & $\begin{array}{l}20, \mathrm{M}, \\
\text { asthmatic }\end{array}$ & $\begin{array}{l}\text { NR, presented with acute } \\
\text { marijuana intoxication }\end{array}$ & Yes & Yes & $\begin{array}{l}\text { Antiemetic therapy prescribed, } \\
\text { pt returned following week } \\
\text { with same symptoms; CHS was } \\
\text { diagnosed, treated with topical } \\
\text { capsaicin }\end{array}$ & $\begin{array}{l}\text { Symptomatic relief occurred } \\
\text { within } 30 \text { min of using } \\
\text { capsaicin; patient was } \\
\text { educated about CHS }\end{array}$ \\
\hline $\begin{array}{l}\text { Gregoire, } 2016 \\
{[126]}\end{array}$ & $\begin{array}{l}27, \mathrm{M} \text {, } \\
\text { bipolar disorder } \\
\text { taking } \mathrm{Rx} \\
\text { lithium }\end{array}$ & $\begin{array}{l}4 \text { wk history nausea, } 3 \mathrm{wk} \\
\text { vomiting, pt } \mathrm{d} / \mathrm{c} \text { lithium } \\
\text { thinking it was causing } \\
\text { symptoms }\end{array}$ & Yes & $\begin{array}{l}14 \mathrm{y} \text {, escalating } \\
\text { use }\end{array}$ & $\begin{array}{l}\text { CHS confirmed when } \mathrm{d} / \mathrm{c} \text { of } \\
\text { marijuana resolved symptoms }\end{array}$ & $\begin{array}{l}25 \mathrm{~d} \text { of inpatient care } \\
\text { required to stabilize } \\
\text { psychiatric drug regimen }\end{array}$ \\
\hline $\begin{array}{l}\text { Habboushe, } 2014 \\
{[137]}\end{array}$ & $25, \mathrm{M}$ & $\begin{array}{l}\text { Intractable vomiting }(>20 / \mathrm{d}) \\
\text { for } 1 \mathrm{~d}\end{array}$ & Yes & $8 \mathrm{y}$ & $\begin{array}{l}\text { Creatinine } 3.21 \mathrm{mg} / \mathrm{dL} \text {, blood } \\
\text { urea nitrogen } 24 \mathrm{mg} / \mathrm{dL} \text {, anion } \\
\text { gap } 34 \text {, diagnosed with acute } \\
\text { renal failure secondary to } \\
\text { dehydration caused by CHS }\end{array}$ & $\begin{array}{l}\text { Pt treated for renal failure } \\
\text { and discharged after short } \\
\text { hospital stay }\end{array}$ \\
\hline Heard, 2017 [170] & $32, \mathrm{M}$ & $\begin{array}{l}12 \mathrm{~h} \text { intractable vomiting, } \\
\text { similar episodes over past } \\
2 \mathrm{mo}\end{array}$ & Yes & $10 \mathrm{y}$ & $\begin{array}{l}\text { CHS, IV haloperidol } 5 \mathrm{mg} \text {, IV } \\
\text { diphenhydramine } \\
\text { hydrochloride } 25 \mathrm{mg}\end{array}$ & $\sim 1 \mathrm{~h}$ \\
\hline Heise, 2015 [139] & $17, \mathrm{M}$ & 3 wk, multiple episodes & Not reported & $\begin{array}{l}\text { Regular use, } \\
\text { marijuana } \\
\text { provided by his } \\
\text { mother to } \\
\text { manage } \\
\text { symptoms }\end{array}$ & $\begin{array}{l}\text { Diagnosed with CVS at first } \\
\text { presentation but antiemetics } \\
\text { not effective; next visit, CHS } \\
\text { diagnosed }\end{array}$ & $48 \mathrm{~h}$ \\
\hline $\begin{array}{l}\text { Hermes-Laufer, } \\
2016[140]\end{array}$ & $\begin{array}{l}26, \mathrm{M}, \\
\text { Gilbert's } \\
\text { syndrome and } \\
\text { myringoplasty }\end{array}$ & $5 y$ & Yes & $\begin{array}{l}\text { Regular use, } \\
\text { duration not } \\
\text { quantified }\end{array}$ & $\begin{array}{l}\text { Initially diagnosed with gall } \\
\text { stones; laparoscopic } \\
\text { cholecystectomy and some } \\
\text { initial improvement; } \\
\text { antiemetics ineffective. } \\
\text { Repeated visits, CHS } \\
\text { diagnosed }\end{array}$ & NR \\
\hline $\begin{array}{l}\text { Hickey, } 2013 \\
{[111]}\end{array}$ & $34, \mathrm{M}$ & $\begin{array}{l}10 \text { y of episodes about every } \\
2-3 \text { mo }\end{array}$ & Yes & $\begin{array}{l}>20 \mathrm{y} \text {, daily use } \\
\text { with short } \\
\text { periods of } \\
\text { abstinence }\end{array}$ & $\begin{array}{l}\text { CHS; IV haloperidol } 5 \mathrm{mg} \text {, } \\
\text { discharged in } 8 \mathrm{~h}\end{array}$ & $1 \mathrm{~h}$ \\
\hline $\begin{array}{l}\text { Iacopetti, } 2014 \\
\text { [19] }\end{array}$ & $\begin{array}{l}33, \mathrm{M}, \mathrm{PTSD}, \\
\text { GERD }\end{array}$ & 2 y (5 hospitalizations) & Yes & $\begin{array}{l}\text { Daily use }>2 \mathrm{y} \\
\text { intermittent use } \\
\text { prior to that }\end{array}$ & $\begin{array}{l}\text { CVS diagnosed initially, } \\
\text { revised to CHS on later ED } \\
\text { visit }\end{array}$ & $\begin{array}{l}\text { Symptoms resolved, pt } \\
\text { resistant to } \mathrm{d} / \mathrm{c} \text { marijuana }\end{array}$ \\
\hline Inayat, 2017 [114] & $27, M$ & $2 y$ & Yes & $10 \mathrm{y}$ & $\begin{array}{l}\text { Pt underwent multiple tests, } \\
\text { CHS, lorazepam ineffective, IV } \\
\text { haloperidol effective }\end{array}$ & $\begin{array}{l}2 \mathrm{~d} \text { in hospital provided no } \\
\text { relief, symptoms resolved } \\
\text { with IV haloperidol }\end{array}$ \\
\hline Ishaq, 2014 [141] & $42, \mathrm{M}$ & 20 y (8 hospitalizations) & Yes & $28 \mathrm{y}$ & $\begin{array}{l}\text { Numerous tests before CHS } \\
\text { diagnosis }\end{array}$ & $\begin{array}{l}\text { Symptoms resolved in } \\
\text { hospital; pt d/c marijuana } \\
\text { and at } 3 \text { mo was symptom- } \\
\text { free }\end{array}$ \\
\hline Jones, 2016 [113] & $18, \mathrm{~F}$ & $1 \mathrm{y}$ & NR & $\begin{array}{l}\text { Regular use, } \\
\text { escalating, not } \\
\text { quantified }\end{array}$ & $\begin{array}{l}\text { CHS, pt resistant; outpatient } \\
\text { treatment with } 5 \mathrm{mg} \\
\text { haloperidol daily }\end{array}$ & $\begin{array}{l}\text { Haloperidol well tolerated, } \\
\text { pt d/c treatment at } 3 \mathrm{wk} \text {, lost } \\
\text { to follow-up }\end{array}$ \\
\hline Kast, 2018 [142] & $21, \mathrm{M}$ & Yes, prior hospitalizations & Yes & $\begin{array}{l}4 \text { y, including } \\
\text { "dabbing" pure } \\
\text { THC on } \\
\text { marijuana } \\
\text { cigarettes }\end{array}$ & $\begin{array}{l}\text { Antiemetics ineffective, CHS } \\
\text { diagnosed; IV haloperidol } 2 \\
\text { mg every } 8 \mathrm{~h} \text { as needed }\end{array}$ & $2 \mathrm{~d}$ \\
\hline $\begin{array}{l}\text { Kraemer, } 2013 \\
{[143]}\end{array}$ & $42, \mathrm{M}$ & NR & Yes & $\begin{array}{l}\text { Long term, not } \\
\text { quantified }\end{array}$ & $\begin{array}{l}\text { Skin rash from hot showers; } \\
\text { CHS }\end{array}$ & Yes but duration of time NR \\
\hline $\begin{array}{l}\text { Mahmad, } 2015 \\
{[144]}\end{array}$ & $32, \mathrm{M}$ & 5 days & Yes & $19 \mathrm{y}$ & CHS & $1 \mathrm{~d}$ \\
\hline $\begin{array}{l}\text { Manoharan, } 2018 \\
{[145]}\end{array}$ & $16, \mathrm{~F}$ & $2 \mathrm{~d}$ & Yes & NR & CHS & Gradual resolution \\
\hline
\end{tabular}


Table 2 (continued)

\begin{tabular}{|c|c|c|c|c|c|c|}
\hline $\begin{array}{l}\text { First author, year } \\
\text { [Ref.] }\end{array}$ & $\begin{array}{l}\text { Age in years, sex, } \\
\text { relevant history }\end{array}$ & Prior reports & Hot showers & $\begin{array}{l}\text { Prior } \\
\text { marijuana use }\end{array}$ & $\begin{array}{l}\text { Diagnosis/ } \\
\text { treatment }\end{array}$ & $\begin{array}{l}\text { Resolution/ } \\
\text { follow-up }\end{array}$ \\
\hline $\begin{array}{l}\text { Manning Meurer, } \\
2018[180]\end{array}$ & $\begin{array}{l}21, \mathrm{~F} \\
\text { primigravida }\end{array}$ & Multiple & NR & NR & $\begin{array}{l}\text { HG initially diagnosed, } \\
\text { positive drug tests revised dx } \\
\text { to CHS at } 30 \text { wk gestation; pt } \\
\text { hospitalized for CHS } \\
\text { symptoms } 9 \mathrm{~d} \text { postpartum }\end{array}$ & NR \\
\hline Miller, 2010 [146] & $\begin{array}{l}17, \mathrm{M} \text {, } \\
\text { ADHD, asthma, } \\
\text { depression }\end{array}$ & $1 \mathrm{y}$ & Yes & $3 y$ & $\begin{array}{l}\text { CVS first dx, counseled to quit } \\
\text { marijuana; dx revised to CHS } \\
\text { when marijuana cessation } \\
\text { resolved symptoms }\end{array}$ & NR \\
\hline Miller, 2010 [146] & $18, \mathrm{~F}$ & $\begin{array}{l}2 \mathrm{y}(10 \text { ED visits and } 3 \\
\text { hospitalizations in } 18 \mathrm{mo})\end{array}$ & Yes & $2 y$ & CHS & NR \\
\hline $\begin{array}{l}\text { Mohammed, } \\
2013 \text { [147] }\end{array}$ & $26, \mathrm{M}$ & $6 \mathrm{mo}$ & Yes & $2 y$ & CHS & $48 \mathrm{~h}$ \\
\hline Moon, 2018 [22] & $47, \mathrm{M}$ & $8 \mathrm{y}$ & NR & $10 \mathrm{y}$ & $\begin{array}{l}\text { CHS but continued use of } \\
\text { marijuana; next ED visit } \\
\text { treated with capsaicin } 0.075 \% \\
\text { every } 4 \mathrm{~h} \text { as needed }\end{array}$ & $4 \mathrm{~h}$ \\
\hline $\begin{array}{l}\text { Morris, } 2014 \\
{[148]}\end{array}$ & $\begin{array}{l}20, \mathrm{~F}, \\
\text { migraineur }\end{array}$ & $9 \mathrm{mo}$ & Yes & $4 y$ & CHS & NR \\
\hline $\begin{array}{l}\text { Muschart, } 2015 \\
\text { [99] }\end{array}$ & $28, \mathrm{M}$ & $4 \mathrm{y}$, about 6 episodes/y & Cold showers & $\begin{array}{l}\text { Several y of daily } \\
\text { use, not } \\
\text { quantified }\end{array}$ & $\begin{array}{l}\text { "Non-classical" CHS, pt } \\
\text { resistant to d/c cannabis; pt } \\
\text { also had bradycardia }\end{array}$ & NR \\
\hline $\begin{array}{l}\text { Nicolson, } 2012 \\
{[149]}\end{array}$ & $\begin{array}{l}22, \mathrm{~F}, \text { low back } \\
\text { pain relieved } \\
\text { with marijuana }\end{array}$ & $\begin{array}{l}5 \mathrm{y} \text {, multiple hospitalizations } \\
\text { and up to } 2 \mathrm{ED} \text { visits/mo }\end{array}$ & Yes & $5 y$ & CHS & $\begin{array}{l}4 \mathrm{~d} \text {, but pt continued } \\
\text { marijuana use and had } \\
\text { further CHS hospitalizations }\end{array}$ \\
\hline $\begin{array}{l}\text { Nicolson, } 2012 \\
{[149]}\end{array}$ & $24, \mathrm{M}$ & $\begin{array}{l}2 \mathrm{y} \text {, episodes every } 2-3 \mathrm{mo} \text {, } \\
\text { multiple hospitalizations }\end{array}$ & Yes & $10 \mathrm{y}$ & CHS & $\begin{array}{l}1 \mathrm{wk} \text {; pt refused further care, } \\
\text { lost to follow-up }\end{array}$ \\
\hline $\begin{array}{l}\text { Nicolson, } 2012 \\
\text { [149] }\end{array}$ & $\begin{array}{l}20, \mathrm{~F}, \\
\text { depression, } \\
\text { anxiety }\end{array}$ & $1.5 \mathrm{y}, 4$ hospitalizations & Yes & $3.5 \mathrm{y}$ & CHS & $2 \mathrm{~d}$ \\
\hline Nogi, 2014 [150] & $\begin{array}{l}32, \mathrm{~F}, \\
\text { migraineur }\end{array}$ & "Several years" & Yes & $>10 y$ & CHS & Nausea persisted \\
\hline $\begin{array}{l}\text { Nourbakhsh, } \\
2018[171]\end{array}$ & $27, \mathrm{~F}$ & $\begin{array}{l}\text { Pt found unresponsive, } \\
\text { emergency services called, } \\
\text { heart rate } 40 \text { beats per } \\
\text { minute, hypoglycemic, } 8 \text { y } \\
\text { history of vomiting; pt had } \\
\text { been in ER } 2 \text { d prior for } \\
\text { intractable vomiting }\end{array}$ & NR & $\begin{array}{l}\text { Long history, not } \\
\text { quantified }\end{array}$ & $\begin{array}{l}\text { Pt developed VF and died } 2 \mathrm{~h} \\
\text { after being brought to ED; } \\
\text { sinus rhythm deteriorated to } \\
\text { ventricular fibrillation; autopsy } \\
\text { stated she died of } \\
\text { complications of CHS }\end{array}$ & Fatality \\
\hline $\begin{array}{l}\text { Nourbakhsh, } \\
2018[171]\end{array}$ & $27, \mathrm{M}$ & $\begin{array}{l}\text { Pt had been vomiting } \\
\text { excessively for } 5-6 \mathrm{~d} \text { before } \\
\text { his death, history of cyclic } \\
\text { vomiting; he was found } \\
\text { deceased }\end{array}$ & NR & $\begin{array}{l}\text { Long history, pt } \\
\text { was in drug rehab } \\
\text { center at the time } \\
\text { of death }\end{array}$ & $\begin{array}{l}\text { Pt was dehydrated with dry } \\
\text { mucus membranes; autopsy } \\
\text { results were death due to } \\
\text { complications of chronic } \\
\text { cannabis use }\end{array}$ & Fatality \\
\hline $\begin{array}{l}\text { Parekh, } 2016 \\
\text { [151] }\end{array}$ & 38, M, GERD & $20 \mathrm{y}, 3-4$ episodes/mo & Yes & $20 \mathrm{y}$ & CHS & $1 \mathrm{~d}$ \\
\hline $\begin{array}{l}\text { Phillips, } 2017 \\
\text { [116] }\end{array}$ & $34, \mathrm{M}$ & $\begin{array}{l}3 \text { y, episodes about } 2 \times \text { per wk, } \\
\text { multiple ED visits }\end{array}$ & Yes & $9 y$ & CHS & NR \\
\hline Price, 2011 [152] & $30, \mathrm{M}$ & $3 \mathrm{~d}$ & Yes & $\begin{array}{l}\text { "Years," not } \\
\text { quantified }\end{array}$ & CHS & $4 \mathrm{~d}$ \\
\hline $\begin{array}{l}\text { Ramadurai, } 2016 \\
{[153]}\end{array}$ & $21, \mathrm{M}$ & $1 \mathrm{y}(5$ hospitalizations in $\mathrm{y})$ & Yes & $2 y$ & CHS & NR \\
\hline $\begin{array}{l}\text { Roca-Pallin, } 2013 \\
{[154]}\end{array}$ & $\begin{array}{l}36, \mathrm{~F}, 2^{\circ} \text { burns } \\
\text { on } 20 \% \text { of body, } \\
\text { anxiety }\end{array}$ & $5 \mathrm{y}$, multiple hospital visits & Yes & $5 y$ & CHS & Several days \\
\hline Roche, 2005 [155] & $21, \mathrm{M}$ & 2 y (7 hospitalizations) & Yes & $\begin{array}{l}\text { Yes, duration not } \\
\text { quantified }\end{array}$ & $\begin{array}{l}\text { CHS, diagnosed when his } \\
\text { girlfriend suggested CHS (and } \\
\text { he fit profile) }\end{array}$ & NR \\
\hline
\end{tabular}


Table 2 (continued)

\begin{tabular}{|c|c|c|c|c|c|c|}
\hline $\begin{array}{l}\text { First author, year } \\
\text { [Ref.] }\end{array}$ & $\begin{array}{l}\text { Age in years, sex, } \\
\text { relevant history }\end{array}$ & Prior reports & Hot showers & $\begin{array}{l}\text { Prior } \\
\text { marijuana use }\end{array}$ & $\begin{array}{l}\text { Diagnosis/ } \\
\text { treatment }\end{array}$ & $\begin{array}{l}\text { Resolution/ } \\
\text { follow-up }\end{array}$ \\
\hline $\begin{array}{l}\text { Sannarangappa, } \\
2009 \text { [156] }\end{array}$ & $\begin{array}{l}34, \mathrm{M} \text {, } \\
\text { abdominal rash } \\
\text { from hot water } \\
\text { bottle }\end{array}$ & $10 \mathrm{y}$ & Yes & $15 y$ & $\begin{array}{l}\text { CHS after pt reported } 2 \text { y } \\
\text { abstinence from marijuana } \\
\text { alleviated symptoms }\end{array}$ & $5 \mathrm{~d}$ \\
\hline Sawni, 2016 [125] & $15, \mathrm{~F}$ & $7 \mathrm{mo}, 4$ hospitalizations & Yes & $\begin{array}{l}>1 \mathrm{y} \text {, escalating } \\
\text { use }\end{array}$ & CHS & NR \\
\hline Sawni, 2016 [125] & $16, \mathrm{~F}$ & $4 \mathrm{mo}, 4$ hospitalizations & Yes & $\begin{array}{l}\text { Yes, not } \\
\text { quantified and } \\
\text { included } \\
\text { secondhand } \\
\text { marijuana smoke } \\
\text { from family }\end{array}$ & CHS & NR \\
\hline $\begin{array}{l}\text { Schmid, } 2011 \\
\text { [157] }\end{array}$ & $\begin{array}{l}26, \mathrm{~F}, 10 \mathrm{wk} \\
\text { pregnant }\end{array}$ & $3.5 \mathrm{y}$, prior hospitalizations & Yes & $13 \mathrm{y}$ & $\begin{array}{l}\text { CHS Pt d/c marijuana about } 10 \\
\mathrm{~d} \text { prior to hospitalization when } \\
\text { she learned she was pregnant }\end{array}$ & $2 \mathrm{wk}$ \\
\hline Singh, 2008 [158] & $46, \mathrm{M}$ & $3 \mathrm{y}$, multiple prior ED visits & Yes & $>30 \mathrm{y}$ & $\begin{array}{l}\text { First CVS, revised to CHS with } \\
\text { cannabis history }\end{array}$ & NR \\
\hline $\begin{array}{l}\text { Sontineni, } 2009 \\
\text { [159] }\end{array}$ & $22, \mathrm{M}$ & $2 \mathrm{mo}, 2$ prior ED visits & Yes & $6 y$ & $\begin{array}{l}\text { CHS after pt disclosed } \\
\text { cannabis use }\end{array}$ & NR \\
\hline Torka, 2012 [160] & $20, \mathrm{M}$ & NR & Yes & $2-3 y$ & $\begin{array}{l}\text { Pancreatitis initial dx, use of } \\
\text { hot showers led to CHS dx }\end{array}$ & NR \\
\hline Torka, 2012 [160] & $29, \mathrm{M}$ & $3 \mathrm{mo}$ & Yes & $3 \mathrm{mo}$ & $\begin{array}{l}\text { ST elevations, pt history led to } \\
\mathrm{dx} \text { of CHS }\end{array}$ & NR \\
\hline $\begin{array}{l}\text { Trappey, } 2017 \\
{[172]}\end{array}$ & $24, \mathrm{M}$ & $\begin{array}{l}\text { Pt had } 25 \text { ED visits and } 6 \\
\text { hospitalizations in past } 4 \text { y for } \\
\text { intractable vomiting; he } \\
\text { vomited for } 2 \mathrm{~d} \text { and was } \\
\text { hospitalized, returned home } \\
\text { and presented at ED } 3 \mathrm{~d} \text { later } \\
\text { with same symptoms }\end{array}$ & $\begin{array}{l}\text { Yes, but when hot } \\
\text { water was not } \\
\text { available he jogged } \\
\text { as exercise reduced } \\
\text { symptoms } \\
\text { resulting in } \\
\text { exercise-induced } \\
\text { rhabdomyolysis } \\
\text { requiring IV } \\
\text { hydration }\end{array}$ & $\begin{array}{l}\text { Described as } \\
\text { "extensive," not } \\
\text { quantified }\end{array}$ & $\begin{array}{l}\text { CHS had been diagnosed } \\
\text { earlier but pt did not } \\
\text { discontinue marijuana, in fact, } \\
\text { he continued its use thinking it } \\
\text { would help symptoms; pt } \\
\text { continues to use marijuana } \\
\text { and has been rehospitalized }\end{array}$ & $24 \mathrm{~h}$ \\
\hline $\begin{array}{l}\text { Valdivielso- } \\
\text { Cortazar, } 2018 \\
{[173]}\end{array}$ & $30, \mathrm{~F}$ & $\begin{array}{l}\text { Cyclic vomiting, abdominal } \\
\text { pain, presented during an } \\
\text { episode of stomach pain, } \\
\text { nausea, and vomiting }\end{array}$ & Yes & $14 \mathrm{y}$ & $\begin{array}{l}\text { CHS was diagnosed and } \\
\text { patient was counseled to } \\
\text { abstain from marijuana }\end{array}$ & NR \\
\hline $\begin{array}{l}\text { Wallace, } 2007 \\
{[161]}\end{array}$ & $30, \mathrm{M}$ & $\begin{array}{l}5 \mathrm{y}, 14 \text { ED visits, } 3 \\
\text { hospitalizations }\end{array}$ & Yes & $16 y$ & $\begin{array}{l}\text { Initial diagnosis was stress- } \\
\text { related vomiting, revised to } \\
\text { PV, then CHS when symptoms } \\
\text { described in } 2004\end{array}$ & NR \\
\hline $\begin{array}{l}\text { Warner, } 2014 \\
{[162]}\end{array}$ & $28, \mathrm{M}$ & 9 mo, repeated ED visits & Yes & $13 y$ & $\begin{array}{l}\text { Pt initially denied use of } \\
\text { marijuana and later minimized } \\
\text { it; diagnosis of CHS when } \\
\text { marijuana use and hot showers } \\
\text { were disclosed }\end{array}$ & NR \\
\hline Wild, 2012 [163] & $21, \mathrm{~F}$ & $4 \mathrm{wk}$ & NR & $7 y$ & $\begin{array}{l}\text { CHS when gastroenteritis was } \\
\text { ruled out (no diarrhea) }\end{array}$ & NR \\
\hline $\begin{array}{l}\text { Williamson, } 2014 \\
{[164]}\end{array}$ & $39, \mathrm{M}$ & $6 y$, at least $2 \times$ per mo & Yes & $20 \mathrm{y}$ & CHS & $48 \mathrm{~h}$ \\
\hline $\begin{array}{l}\text { Williamson, } 2014 \\
{[164]}\end{array}$ & $19, \mathrm{M}$ & $2 \mathrm{wk}$ & NR & $2 y$ & CHS & $48 \mathrm{~h}$ \\
\hline $\begin{array}{l}\text { Woods, } 2016 \\
{[165]}\end{array}$ & $37, \mathrm{M}$ & $14 \mathrm{y}, 18$ admissions in past $5 \mathrm{y}$ & Yes & $\begin{array}{l}\text { "Long term" not } \\
\text { quantified }\end{array}$ & CHS & $4 \mathrm{~d}$ \\
\hline \multicolumn{7}{|c|}{ Synthetic marijuana } \\
\hline $\begin{array}{l}\text { Argamany, } 2016 \\
{[166]}\end{array}$ & $27, \mathrm{M}$ & $1 \mathrm{wk}$ & NR & $\begin{array}{l}\text { Recent use of } \\
\text { synthetic } \\
\text { marijuana }\end{array}$ & $\begin{array}{l}\text { Acute renal failure attributed } \\
\text { to rhabdomyolysis secondary } \\
\text { to CHS }\end{array}$ & $\begin{array}{l}\text { Emergent hemodialysis not } \\
\text { needed and kidney function } \\
\text { returned to normal in about } \\
1 \mathrm{wk}\end{array}$ \\
\hline
\end{tabular}


Table 2 (continued)

\begin{tabular}{|c|c|c|c|c|c|c|}
\hline $\begin{array}{l}\text { First author, year } \\
\text { [Ref.] }\end{array}$ & $\begin{array}{l}\text { Age in years, sex, } \\
\text { relevant history }\end{array}$ & Prior reports & Hot showers & $\begin{array}{l}\text { Prior } \\
\text { marijuana use }\end{array}$ & $\begin{array}{l}\text { Diagnosis/ } \\
\text { treatment }\end{array}$ & $\begin{array}{l}\text { Resolution/ } \\
\text { follow-up }\end{array}$ \\
\hline Bick, 2014 [167] & $29, \mathrm{M}$ & $\begin{array}{l}\text { Recurrent episodes, sought } \\
\text { help at PC, then ED }\end{array}$ & Yes & $\begin{array}{l}\text { Patient denied } \\
\text { use of marijuana } \\
\text { and tested } \\
\text { negative for THC } \\
\text { but used K2 and } \\
\text { Kryptonite } \\
\text { (synthetic } \\
\text { marijuana) } \\
\text { regularly }\end{array}$ & CHS & $6 \mathrm{mo}$ \\
\hline $\begin{array}{l}\text { Hopkins, } 2013 \\
{[168]}\end{array}$ & $30, \mathrm{M}$ & $2 y$ & Yes & $\begin{array}{l}17 \mathrm{y} \text {, then drug } \\
\text { testing required } \\
\text { for parole led him } \\
\text { to daily use of } \\
\text { undetectable } \\
\text { synthetics, K2, } \\
\text { Spice, Scooby } \\
\text { Snacks }\end{array}$ & CHS & $\begin{array}{l}\text { Symptoms resolved in } 2 \mathrm{wk} \text {; } \\
\text { all marijuana } \mathrm{d} / \mathrm{c} \text { and } \mathrm{pt} \\
\text { symptom-free at } 3 \mathrm{mo}\end{array}$ \\
\hline $\begin{array}{l}\text { Ukaigwe, } 2014 \\
{[169]}\end{array}$ & $38, \mathrm{M}$ & $\begin{array}{l}\text { NR but past episodes had } \\
\text { occurred }\end{array}$ & Yes & $\begin{array}{l}\text { NR but described } \\
\text { as "long term": } \\
\text { use of marijuana } \\
\text { and synthetics }\end{array}$ & $\begin{array}{l}\text { CHS with prerenal acute } \\
\text { kidney injury }\end{array}$ & $\begin{array}{l}2 \text { wk (both CHS and renal } \\
\text { symptoms) }\end{array}$ \\
\hline
\end{tabular}

ADHD, attention deficit hyperactivity disorder; CHS, cannabinoid hyperemesis syndrome; d, day; d/c, discontinued, discontinuation; ED, emergency department; F, female; GERD, gastroesophageal reflux disorder; h, hour; HG, hyperemesis gravidarum; M, male; MDD, major depressive disorder; NR, not reported; PC, primary care; pt, patient; PTSD, posttraumatic stress disorder; Rx, prescribed/prescription; SUD, substance use disorder; wk, week; y, year(s); yo, years old. Studies are presented in alphabetical order by last name of first author of the report, and studies involving specifically synthetic cannabinoids appear at the end. As these case studies were conducted independently and did not always report the same data (for instance, some had no data on treatment or resolution or prior marijuana use), it was not possible to synthesize this information in any scientifically sound or clinically meaningful way. It is fair to glean from the chart some basic information, namely that no patient from a case study is $>51$ years old, the majority are men with a long history of marijuana use, many had previous encounters with the healthcare system before CHS was diagnosed, most found relief in hot showers, and, when reported, symptoms typically resolved in a short time when marijuana was discontinued.

\section{Skin Conditions}

A 42-year-old CHS patient treated for hyperemesis in the hospital presented with a reddish-brown pigmented rash on his trunk and extremities. The rash could be diagnosed as erythema ad igne or thermal keratosis. The patient reported that he got the rash from prolonged exposure to hot water in showers that he took to relieve the symptoms of his CHS [143]. Cutaneous problems arise typically from prolonged and excessive exposure to very hot water, heating pads, or hot water bottles.

\section{Cardiac Conditions}

CB-1 receptors are present in the heart, which makes it possible that cannabinoids might affect myocardial performance [150]. Preclinical studies suggest that endocannabinoids and THC may evoke bradycardia, hypotension, and decreased contractility of the myocardial tissue [149]. The mechanism by which THC and cannabinoids might decrease myocardial contractility remains to be elucidated. A case report in the literature describes Takotsubo syndrome or stress cardiomyopathy in a patient with CHS [150]. However, this finding may be coincidental.

\section{Discussion}

As CHS becomes an increasingly familiar diagnosis to clinicians, particularly in those regions of the world with liberalized or prevalent marijuana use, there still remain some puzzling questions. The pathogenesis of CHS is being elucidated and likely involves a prominent role of TRPV1 receptors. But why is CHS an episodic condition with sometimes very long asymptomatic periods between attacks? [90]. It would seem that persistent use of marijuana should provoke persistent or at least protracted symptoms, but nearly all CHS patients report long asymptomatic breaks between relatively short symptomatic episodes while they continue to use marijuana. Another puzzling question is why CHS symptoms in many patients resolve completely in a very short period of time even hours - when marijuana use is discontinued. Further study is needed.

Better clinical education about CHS is needed. Nausea, vomiting, and abdominal pain are diffuse symptoms that may derive from any of several diverse etiologies. Since such symptoms could indicate a serious, even potentially life-threatening, condition before their diagnosis, pa- 
tients with CHS are often subjected to computed tomography scans, magnetic resonance imaging procedures, exploratory procedures, endoscopy, colonoscopy, gastric emptying tests, and a battery of lab work. For CHS patients, these tests typically offer normal-range results, but they are expensive, time-consuming, and place a hardship on the patient as well as the healthcare system. Thus, prompt diagnosis of CHS can save valuable clinical time and resources.

CHS patients are often resistant to finding out that marijuana causes their symptoms. Many CHS patients are long-term marijuana users who object to marijuana discontinuation, even though it provokes symptoms severe enough to require hospitalization. This leads to an important question, especially in light of our gradual societal paradigm shift toward liberalizing marijuana. Is marijuana addictive? Certainly marijuana use disorder exists, but it is not clear if it is addictive in the same manner as opioids or alcohol. The refusal of many CHS patients to give up marijuana despite debilitating symptoms certainly suggests that marijuana may be far more addictive than previously believed and/or that prolonged marijuana use impairs an individual's ability to make sound decisions.

With many states legalizing the use of both medical and nonmedical marijuana and increasingly favorable public opinion emphasizing the benefits marijuana, it is reasonable to expect its use will become more frequent and widespread. The National Institute on Drug Abuse estimates that in 2013 there were about 19.8 million active marijuana users in the US (6.3\% of total population), concentrated among younger people, and that $22.6 \%$ of Americans between the ages of 18 and 20 are marijuana users [179]. This in turn may lead to more and more cases of CHS.

\section{Limitations}

This is a literature review and it has inherent limitations. There is currently not a vast amount of medical lit- erature about CHS, and most of the clinical reports are case reports of individuals or small case series, which do not provide high-quality medical evidence. The heterogeneity of the case reporting makes data synthesis impossible.

\section{Conclusion}

CHS is a distinct clinical condition that differs from CVS or other vomiting disorders in that it occurs in individuals with long-term marijuana use who experience episodes of nausea and intractable vomiting that can be relieved with hot showers or topical capsaicin. Many clinicians and the general public - including avid marijuana users - are unaware of the existence of CHS, and many patients undergo unnecessary tests, scans, and procedures to get at the root of their sometimes debilitating symptoms. CHS resolves quickly and completely with the cessation of marijuana. With the liberalization of marijuana laws and growing favorable public opinion about the benefits of marijuana, CHS is likely to become increasingly more common.

\section{Acknowledgement}

The authors wish to thank Claudia Bonar, $\mathrm{RN}$, for reading the manuscript and providing us with helpful comments and suggestions.

\section{Disclosure Statement}

None of the authors have any conflicts of interest.

\section{Author Contributions}

All authors contributed to the manuscript.

\section{References}

1 Allen JH, de Moore GM, Heddle R, Twartz JC. Cannabinoid hyperemesis: cyclical hyperemesis in association with chronic cannabis abuse. Gut. 2004 Nov;53(11):1566-70.

2 Sullivan S. Cannabinoid hyperemesis. Can J Gastroenterol. 2010;24(5):284-285.

3 National Institute on Drug Abuse. What is the scope of marijuana use in the United States?
Marijuana Res Rep Ser 2018; https://www drugabuse.gov/publications/research-reports/marijuana/what-scope-marijuana-usein-united-states. Accessed May 16, 2018.

4 Ogden D. Memorandum for Selected US Attorneys. 2009; https://www.justice.gov/sites/ default/files/opa/legacy/2009/10/19/medicalmarijuana.pdf. Accessed May 16, 2018.
5 Al-Shammari M, Herrera K, Liu X, et al. Effects of the 2009 Medical Cannabinoid Legalization Policy on Hospital Use for Cannabinoid Dependency and Persistent Vomiting. Clin Gastroenterol Hepatol. 2017;15(12):1876-81.

6 Fleig S, Brunkhorst R. Hyperemesis and a high water bill. Z Gastroenterol. 2011 Nov; 49(11):1479-81. 
7 Figueroa-Rivera IM, Estremera-Marcial R, Sierra-Mercado M, Gutiérrez-Núñez J, Toro DH. Cannabinoid Hyperemesis Syndrome: A Paradoxical Cannabis Effect. Case Rep Gastrointest Med. 2015;2015:405238.

8 Francis $\mathrm{H}$. Emerging role of chronic cannabis usage and hyperemesis syndrome. South Med J. 2011 Sep;104(9):665.

9 United Nations Office on Drugs and Crime. Why does cannabis potency matter? World Drug Report 2009 Series 2009; http://www. unodc.org/unodc/en/frontpage/2009/June/ why-does-cannabis-potency-matter.html. Accessed May 18, 2018.

10 Cox B, Chhabra A, Adler M, Simmons J, Randlett D. Cannabinoid hyperemesis syndrome: case report of a paradoxical reaction with heavy marijuana use. Case Rep Med. 2012;2012:757696.

11 Freeman TP, van der Pol P, Kuijpers W, Wisselink J, Das RK, Rigter S, et al. Changes in cannabis potency and first-time admissions to drug treatment: a 16-year study in the Netherlands. Psychol Med. 2018 Oct;48(14): 2346-52.

12 Smart R, Caulkins JP, Kilmer B, Davenport S, Midgette G. Variation in cannabis potency and prices in a newly legal market: evidence from 30 million cannabis sales in Washington state. Addiction. 2017 Dec;112(12):2167-77.

13 Galli JA, Sawaya RA, Friedenberg FK. Cannabinoid hyperemesis syndrome. Curr Drug Abuse Rev. 2011 Dec;4(4):241-9.

14 Sun S, Zimmermann AE. Cannabinoid hyperemesis syndrome. Hosp Pharm. 2013 Sep; 48(8):650-5.

15 Blumentrath CG, Dohrmann B, Ewald N. Cannabinoid hyperemesis and the cyclic vomiting syndrome in adults: recognition, diagnosis, acute and long-term treatment. Ger Med Sci. 2017 Mar 21;15:Doc06.

16 Darmani NA. Cannabinoid-Induced Hyperemesis: A Conundrum-From Clinical Recognition to Basic Science Mechanisms. Pharmaceuticals (Basel). 2010 Jul;3(7):2163-77.

17 Darmani NA. The potent emetogenic effects of the endocannabinoid, 2-AG (2-arachidonoylglycerol) are blocked by delta(9)-tetrahydrocannabinol and other cannnabinoids. J Pharmacol Exp Ther. 2002 Jan;300(1):34-42.

18 Howlett AC, Johnson MR, Melvin LS, Milne GM. Nonclassical cannabinoid analgetics inhibit adenylate cyclase: development of a cannabinoid receptor model. Mol Pharmacol. 1988 Mar;33(3):297-302.

19 Iacopetti CL, Packer CD. Cannabinoid hyperemesis syndrome: a case report and review of pathophysiology. Clin Med Res. 2014 Sep; 12(1-2):65-7.

20 Mackie K. Cannabinoid receptors: where they are and what they do. J Neuroendocrinol. 2008 May;20(s1 Suppl 1):10-4.

21 Iannotti FA, Hill CL, Leo A, Alhusaini A, Soubrane C, Mazzarella E, et al. Nonpsychotropic plant cannabinoids, cannabidivarin (CBDV) and cannabidiol (CBD), activate and desensitize transient receptor potential vanilloid 1
(TRPV1) channels in vitro: potential for the treatment of neuronal hyperexcitability. ACS Chem Neurosci. 2014 Nov;5(11):1131-41.

22 Moon AM, Buckley SA, Mark NM. Successful Treatment of Cannabinoid Hyperemesis Syndrome with Topical Capsaicin. ACG Case Rep J. 2018 Jan;5:e3.

23 Rudd JA, Nalivaiko E, Matsuki N, Wan C, Andrews PL. The involvement of TRPV1 in emesis and anti-emesis. Temperature (Austin). 2015 May;2(2):258-76.

24 Geraghty DP, Mazzone SB, Carter C, Kunde DA. Effects of systemic capsaicin treatment on TRPV1 and Tachykinin NK(1) receptor distribution and function in the nucleus of the solitary tract of the adult rat. Pharmacology. 2011;87(3-4):214-23.

25 Joseph J, Wang S, Lee J, Ro JY, Chung MK. Carboxyl-terminal domain of transient receptor potential vanilloid 1 contains distinct segments differentially involved in capsaicinand heat-induced desensitization. J Biol Chem. 2013 Dec;288(50):35690-702.

26 Darmani NA, Chebolu S, Zhong W, Trinh C, McClanahan B, Brar RS. Additive antiemetic efficacy of low-doses of the cannabinoid $\mathrm{CB}(1 / 2)$ receptor agonist $\Delta(9)$ - $\mathrm{THC}$ with ultralow-doses of the vanilloid TRPV1 receptor agonist resiniferatoxin in the least shrew (Cryptotis parva). Eur J Pharmacol. 2014 Jan; 722:147-55.

27 Izzo AA, Camilleri M. Emerging role of cannabinoids in gastrointestinal and liver diseases: basic and clinical aspects. Gut. 2008 Aug; 57(8):1140-55.

28 Iversen L. Cannabis and the brain. Brain. 2003 Jun;126(Pt 6):1252-70.

29 Pertwee RG. Pharmacology of cannabinoid receptor ligands. Curr Med Chem. 1999 Aug; 6(8):635-64.

30 Giuffrida A, Beltramo M, Piomelli D. Mechanisms of endocannabinoid inactivation: biochemistry and pharmacology. J Pharmacol Exp Ther. 2001 Jul;298(1):7-14.

31 Ramírez J, Innocenti F, Schuetz EG, Flockhart DA, Relling MV, Santucci R, et al. CYP2B6, CYP3A4, and CYP2C19 are responsible for the in vitro $\mathrm{N}$-demethylation of meperidine in human liver microsomes. Drug Metab Dispos. 2004 Sep;32(9):930-6.

32 Grotenhermen F. Pharmacokinetics and pharmacodynamics of cannabinoids. Clin Pharmacokinet. 2003;42(4):327-60.

33 Watanabe K, Matsunaga T, Yamamoto I, Funae Y, Yoshimura H. Involvement of CYP2C in the metabolism of cannabinoids by human hepatic microsomes from an old woman. Biol Pharm Bull. 1995 Aug;18(8):1138-41.

34 Kreuz DS, Axelrod J. Delta-9-tetrahydrocannabinol: localization in body fat. Science. 1973 Jan;179(4071):391-3.

35 Gunasekaran N, Long LE, Dawson BL, Hansen GH, Richardson DP, Li KM, et al. Reintoxication: the release of fat-stored delta(9)-tetrahydrocannabinol (THC) into blood is enhanced by food deprivation or ACTH exposure. $\mathrm{Br} \mathrm{J}$ Pharmacol. 2009 Nov;158(5):1330-7.
36 Waterson Duncan R, Maguire M. Capsaicin topical in emergency department treatment of cannabinoid hyperemesis syndrome. Am J Emerg Med. 2017 Dec;35(12):1977-8.

37 Parker LA, Kwiatkowska M, Burton P, Mechoulam R. Effect of cannabinoids on lithium-induced vomiting in the Suncus murinus (house musk shrew). Psychopharmacology (Berl). 2004 Jan;171(2):156-61.

38 Rock EM, Goodwin JM, Limebeer CL, Breuer A, Pertwee RG, Mechoulam R, et al. Interaction between non-psychotropic cannabinoids in marihuana: effect of cannabigerol (CBG) on the anti-nausea or anti-emetic effects of cannabidiol (CBD) in rats and shrews. Psychopharmacology (Berl). 2011 Jun;215(3):505-12.

39 Cheung E, Ng C, Foote J. A hot mess: a case of hyperemesis. Can Fam Physician. 2014 Jul; 60(7):633-7.

40 Del Mar Ramirez Fernandez M, De Boeck G, Wood M, Lopez-Rivadulla M, Samyn N. Simultaneous analysis of THC and its metabolites in blood using liquid chromatographytandem mass spectrometry. J Chromatogr B Analyt Technol Biomed Life Sci. 2008 Nov; 875(2):465-70.

41 Perez-Reyes M, Timmons MC, Lipton MA, Davis $\mathrm{KH}$, Wall ME. Intravenous injection in man of 9 -tetrahydrocannabinol and $11-\mathrm{OH}$ 9 -tetrahydrocannabinol. Science. 1972 Aug; 177(4049):633-5.

42 Burstein SH. The cannabinoid acids: nonpsychoactive derivatives with therapeutic potential. Pharmacol Ther. 1999 Apr;82(1):87-96.

43 Russo EB, Burnett A, Hall B, Parker KK. Agonistic properties of cannabidiol at 5-HT1a receptors. Neurochem Res. 2005 Aug;30(8): 1037-43.

44 Hayakawa K, Mishima K, Hazekawa M, Sano $\mathrm{K}$, Irie K, Orito K, et al. Cannabidiol potentiates pharmacological effects of Delta(9)-tetrahydrocannabinol via $\mathrm{CB}(1)$ receptor-dependent mechanism. Brain Res. 2008 Jan;1188: $157-64$.

45 Kwiatkowska M, Parker LA, Burton P, Mechoulam R. A comparative analysis of the potential of cannabinoids and ondansetron to suppress cisplatin-induced emesis in the Suncus murinus (house musk shrew). Psychopharmacology (Berl). 2004 Jul;174(2):254-9.

46 Cascio MG, Gauson LA, Stevenson LA, Ross RA, Pertwee RG. Evidence that the plant cannabinoid cannabigerol is a highly potent alpha2-adrenoceptor agonist and moderately potent $5 \mathrm{HT} 1 \mathrm{~A}$ receptor antagonist. $\mathrm{Br} \mathrm{J}$ Pharmacol. 2010 Jan;159(1):129-41.

47 Ware MA, Daeninck P, Maida V. A review of nabilone in the treatment of chemotherapyinduced nausea and vomiting. Ther Clin Risk Manag. 2008 Feb;4(1):99-107.

48 Pertwee RG. Cannabinoids and the gastrointestinal tract. Gut. 2001 Jun;48(6):859-67.

49 Krowicki ZK, Moerschbaecher JM, Winsauer PJ, Digavalli SV, Hornby PJ. Delta9-tetrahydrocannabinol inhibits gastric motility in the rat through cannabinoid CB1 receptors. Eur J Pharmacol. 1999 Apr;371(2-3):187-96. 
50 Izzo AA, Mascolo N, Capasso R, Germanò MP, De Pasquale R, Capasso F. Inhibitory effect of cannabinoid agonists on gastric emptying in the rat. Naunyn Schmiedebergs Arch Pharmacol. 1999 Aug;360(2):221-3.

51 McCallum RW, Soykan I, Sridhar KR, Ricci DA, Lange RC, Plankey MW. Delta-9-tetrahydrocannabinol delays the gastric emptying of solid food in humans: a double-blind, randomized study. Aliment Pharmacol Ther. 1999 Jan;13(1):77-80.

52 Esfandyari T, Camilleri M, Ferber I, Burton D, Baxter K, Zinsmeister AR. Effect of a cannabinoid agonist on gastrointestinal transit and postprandial satiation in healthy human subjects: a randomized, placebo-controlled study. Neurogastroenterol Motil. 2006 Sep; 18(9):831-8.

53 Parkman HP, Fass R, Foxx-Orenstein AE. Treatment of patients with diabetic gastroparesis. Gastroenterol Hepatol (N Y). 2010 Jun; 6(6):1-16

54 Camilleri M. Cannabinoids and gastrointestinal motility: Pharmacology, clinical effects, and potential therapeutics in humans. Neurogastroenterol Motil. 2018 Sep;30(9):e13370.

55 Richards JR. Cannabinoid hyperemesis syndrome: A disorder of the HPA axis and sympathetic nervous system? Med Hypotheses. 2017 Jun; 103:90-5.

56 Smith SM, Vale WW. The role of the hypothalamic-pituitary-adrenal axis in neuroendocrine responses to stress. Dialogues Clin Neurosci. 2006;8(4):383-95.

57 Herman JP, Figueiredo H, Mueller NK, UlrichLai Y, Ostrander MM, Choi DC, et al. Central mechanisms of stress integration: hierarchical circuitry controlling hypothalamo-pituitaryadrenocortical responsiveness. Front Neuroendocrinol. 2003 Jul;24(3):151-80.

58 Tsigos C, Chrousos GP. Hypothalamic-pituitary-adrenal axis, neuroendocrine factors and stress. J Psychosom Res. 2002 Oct;53(4): $865-71$.

59 Cota D, Steiner MA, Marsicano G, Cervino C, Herman JP, Grübler Y, et al. Requirement of cannabinoid receptor type 1 for the basal modulation of hypothalamic-pituitary-adrenal axis function. Endocrinology. 2007 Apr; 148(4):1574-81.

60 Tasker JG, Chen C, Fisher MO, Fu X, Rainville JR, Weiss GL. Endocannabinoid Regulation of Neuroendocrine Systems. Int Rey Neurobiol. 2015;125:163-201.

61 Soriano-Co M, Batke M, Cappell MS. The cannabis hyperemesis syndrome characterized by persistent nausea and vomiting, abdominal pain, and compulsive bathing associated with chronic marijuana use: a report of eight cases in the United States. Dig Dis Sci. 2010 Nov;55(11):3113-9.

62 Vaziri ND, Thomas R, Sterling M, Seiff K, Pahl MV, Davila J, et al. Toxicity with intravenous injection of crude marijuana extract. Clin Toxicol. 1981 Mar;18(3):353-66.

63 Frytak S, Moertel CG, O'Fallon JR, Rubin J, Creagan ET, O'Connell MJ, et al. Delta-9-tet- rahydrocannabinol as an antiemetic for patients receiving cancer chemotherapy. A comparison with prochlorperazine and a placebo. Ann Intern Med. 1979 Dec;91(6):825-30.

64 Noyes R Jr, Brunk SF, Avery DA, Canter AC. The analgesic properties of delta-9-tetrahydrocannabinol and codeine. Clin Pharmacol Ther. 1975 Jul;18(1):84-9.

65 Orr LE, McKernan JF, Bloome B. Antiemetic effect of tetrahydrocannabinol. Compared with placebo and prochlorperazine in chemotherapy-associated nausea and emesis. Arch Intern Med. 1980 Nov;140(11):1431-3.

66 Martin B. The use of cannabinoids in patients with chronic illness. US Pharm. 2002;27:6170.

67 Subritzky T, Pettigrew S, Lenton S. Into the void: regulating pesticide use in Colorado's commercial cannabis markets. Int J Drug Policy. 2017 Apr;42:86-96.

68 Voelker R, Holmes M. Pesticide use on cannabis. 2015; http://cannabissafetyinstitute.org/ wp-content/uploads/2015/06/CSI-PesticidesWhite-Paper.pdf. Accessed May 22, 2018.

69 Stogner JM, Miller BL. Assessing the dangers of "dabbing": mere marijuana or harmful new trend? Pediatrics. 2015 Jul;136(1):1-3.

70 Subritzky T, Lenton S, Pettigrew S. Legal cannabis industry adopting strategies of the tobacco industry. Drug Alcohol Rev. 2016 Sep; 35(5):511-3.

71 Bruguera P, Lopez-Pelayo H, Miquel L, Balcells-Olivero M. [High prevalence of cannabinoid hyperemesis syndrome in marijuana users]. Emergencias. 2016;28(4):249-51.

72 Habboushe J, Rubin A, Liu H, Hoffman RS The Prevalence of Cannabinoid Hyperemesis Syndrome Among Regular Marijuana Smokers in an Urban Public Hospital. Basic Clin Pharmacol Toxicol. 2018 Jun;122(6):660-2.

73 Hernandez JM, Paty J, Price IM. Cannabinoid hyperemesis syndrome presentation to the emergency department: A two-year multicentre retrospective chart review in a major urban area. CJEM. 2018 Jul;20(4):550-55.

74 Kim HS, Anderson JD, Saghafi O, Heard KJ, Monte AA. Cyclic vomiting presentations following marijuana liberalization in Colorado. Acad Emerg Med. 2015 Jun;22(6):694-9.

75 Simonetto DA, Oxentenko AS, Herman ML, Szostek JH. Cannabinoid hyperemesis: a case series of 98 patients. Mayo Clin Proc. 2012; 87(2):114-119.

76 Felton D, Zitomersky N, Manzi S, Lightdale JR. 13-year-old girl with recurrent, episodic, persistent vomiting: out of the pot and into the fire. Pediatrics. 2015 Apr;135(4):e1060-3.

77 Moeller K, Lee K, Kissack J. Urine drug screening: practical guide for clinicians. Mayo Clin Proc. 2008;83(1):66-76.

78 Rollins D, Jennison T, Jones GP. Investigation of interference by nonsteroidal anti-inflammatory drugs in urine tests for abused drugs. Clin Chem. 1990;36(4):602-6.

79 Rossi S, Yaksh T, Bentley H, van den Brande G, Grant I, Ellis R. Characterization of interference with 6 commercial delta9-tetrahydro- cannabinol immunoassays by efavirenz (glucuronide) in urine. Clin Chem. 2006 May; 52(5):896-7.

80 Sorensen CJ, DeSanto K, Borgelt L, Phillips KT, Monte AA. Cannabinoid Hyperemesis Syndrome: Diagnosis, Pathophysiology, and Treatment-a Systematic Review. J Med Toxicol. 2017 Mar;13(1):71-87.

81 de Moore GM, Baker J, Bui T. Psychogenic vomiting complicated by marijuana abuse and spontaneous pneumomediastinum. Aust N Z J Psychiatry. 1996 Apr;30(2):290-4.

82 Bhandari S, Jha P, Thakur A, Kar A, Gerdes $\mathrm{H}$, Venkatesan T. Cyclic vomiting syndrome: epidemiology, diagnosis, and treatment. Clin Auton Res. 2018 Apr;28(2):203-9.

83 Donnet A, Redon S. Cyclic Vomiting Syndrome in Children. Curr Pain Headache Rep. 2018 Mar;22(4):30.

84 Millichap JG. Prognosis of Cyclic Vomiting Syndrome. Pediatr Neurol Briefs. 2016 Jan; 30(1):6.

85 Rashed H, Abell TL, Familoni BO, Cardoso S. Autonomic function in cyclic vomiting syndrome and classic migraine. Dig Dis Sci. 1999 Aug;44(8 Suppl):74S-8S

86 Redon S, Mareau C, Guedj E, Donnet A. Cyclic Vomiting Syndrome in Adults and Children: A Hypothesis. Headache. 2017 Jun: 57(6):943-51.

87 Drossman DA. Functional Gastrointestinal Disorders: History, Pathophysiology, Clinical Features and Rome IV. Gastroenterology. 2016 Feb;150(6):S0016-5085(16)00223-7.

88 Stanghellini V, Chan FK, Hasler WL, Malagelada JR, Suzuki H, Tack J, et al. Gastroduodenal Disorders. Gastroenterology. 2016 May; 150(6):1380-92.

89 Fleisher DR, Gornowicz B, Adams K, Burch R, Feldman EJ. Cyclic Vomiting Syndrome in 41 adults: the illness, the patients, and problems of management. BMC Med. 2005 Dec; 3(20):20.

90 Pattathan MB, Hejazi RA, McCallum RW. Association of marijuana use and cyclic vomiting syndrome. Pharmaceuticals (Basel). 2012 Jun;5(7):719-26.

91 Nagarwala J, Dev S, Markin A. The Vomiting Patient: Small Bowel Obstruction, Cyclic Vomiting, and Gastroparesis. Emerg Med Clin North Am. 2016 May;34(2):271-91.

92 Venkatesan T, Sengupta J, Lodhi A, Schroeder A, Adams K, Hogan WJ, et al. An Internet survey of marijuana and hot shower use in adults with cyclic vomiting syndrome (CVS). Exp Brain Res. 2014;232(8):2563-70.

93 Khattar N, Routsolias JC. Emergency Department Treatment of Cannabinoid Hyperemesis Syndrome: A Review. Am J Ther. 2018 May/Jun;25(3):e357-61.

94 Enuh HA, Chin J, Nfonoyim J. Cannabinoid hyperemesis syndrome with extreme hydrophilia. Int J Gen Med. 2013 Aug;6:685-7.

95 Burillo-Putze G, Llorens P, Roman F. Use of Capsaicin Cream in Cannabis Hyperemesis Syndrome. J Emerg Med. 2017 May;52(5): 760 
96 Dezieck L, Hafez Z, Conicella A, Blohm E, O'Connor MJ, Schwarz ES, et al. Resolution of cannabis hyperemesis syndrome with topical capsaicin in the emergency department: a case series. Clin Toxicol (Phila). 2017 Sep;55(8):908-13.

97 Graham J, Barberio M, Wang GS. Capsaicin Cream for Treatment of Cannabinoid Hyperemesis Syndrome in Adolescents: A Case Series. Pediatrics. 2017 Dec;140(6):e20163795.

98 Wallace EA, Andrews SE, Garmany CL, Jelley MJ. Cannabinoid hyperemesis syndrome: literature review and proposed diagnosis and treatment algorithm. South Med J. 2011 Sep;104(9):659-64.

99 Muschart X, Flament J. A non-classical cannabinoid syndrome. Acta Clin Belg. 2015 Aug;70(4):299-300.

100 Lapoint J, Meyer S, Yu CK, Koenig KL, Lev $\mathrm{R}$, Thihalolipavan S, et al. Cannabinoid Hyperemesis Syndrome: Public Health Implications and a Novel Model Treatment Guideline. West J Emerg Med. 2018 Mar; 19(2):380-6.

101 Chang YH, Windish DM. Cannabinoid hyperemesis relieved by compulsive bathing. Mayo Clinic Proc. 2009;84(1):76-78.

102 Patterson DA, Smith E, Monahan M, Medvecz A, Hagerty B, Krijger L, et al. Cannabinoid hyperemesis and compulsive bathing: a case series and paradoxical pathophysiological explanation. J Am Board Fam Med. 2010 Nov-Dec;23(6):790-3.

103 Fernandes ES, Fernandes MA, Keeble JE. The functions of TRPA1 and TRPV1: moving away from sensory nerves. Br J Pharmacol. 2012 May;166(2):510-21.

104 Yang F, Xiao X, Cheng W, Yang W, Yu P, Song Z, et al. Structural mechanism underlying capsaicin binding and activation of the TRPV1 ion channel. Nat Chem Biol. 2015 Jul;11(7):518-24.

105 Bagdure S, Smalligan RD, Sharifi H, Khandheria $\mathrm{B}$. Waning effect of compulsive bathing in cannabinoid hyperemesis. Am J Addict. 2012;21(2):184-185.

106 Ellison N, Loprinzi CL, Kugler J, Hatfield AK, Miser A, Sloan JA, et al. Phase III placebo-controlled trial of capsaicin cream in the management of surgical neuropathic pain in cancer patients. J Clin Oncol. 1997 Aug; 15(8):2974-80.

107 Richards JR, Lapoint JM, Burillo-Putze G. Cannabinoid hyperemesis syndrome: potential mechanisms for the benefit of capsaicin and hot water hydrotherapy in treatment. Clin Toxicol (Phila). 2018 Jan;56(1): $15-24$.

108 Babbar S, Marier JF, Mouksassi MS, Beliveau M, Vanhove GF, Chanda S, et al. Pharmacokinetic analysis of capsaicin after topical administration of a high-concentration capsaicin patch to patients with peripheral neuropathic pain. Ther Drug Monit. 2009 Aug; 31(4):502-10.

109 Babbar S, Chanda S, Bley K. Inhibition and induction of human cytochrome P450 en- zymes in vitro by capsaicin. Xenobiotica. 2010;40(12):807-816.

110 Chanda S, Bashir M, Babbar S, Koganti A, Bley K. In vitro hepatic and skin metabolism of capsaicin. Drug Metab Dispos. 2008 Apr; 36(4):670-5.

111 Hickey JL, Witsil JC, Mycyk MB. Haloperidol for treatment of cannabinoid hyperemesis syndrome. Am J Emerg Med. 2013 Jun; 31(6):1003.e5-6.

112 Routsolias JC. In Response to: Cannabinoid Hyperemesis Syndrome: Diagnosis, Pathophysiology, and Treatment-a Systematic Review. J Med Toxicol. 2017 Jun;13(2):197.

113 Jones JL, Abernathy KE. Successful Treatment of Suspected Cannabinoid Hyperemesis Syndrome Using Haloperidol in the Outpatient Setting. Case Rep Psychiatry. 2016; 2016:3614053.

114 Inayat F, Virk HU, Ullah W, Hussain Q. Is haloperidol the wonder drug for cannabinoid hyperemesis syndrome? BMJ Case Rep. 2017 Jan 4;2017.

115 Witsil JC, Mycyk MB. Haloperidol, a Novel Treatment for Cannabinoid Hyperemesis Syndrome. Am J Ther. 2017 Jan/Feb; 24(1):e64-7.

116 Phillips HR 3rd, Smith DA. A patient with a curious case of cyclical vomiting. JAAPA. 2017 Feb;30(2):1-3.

117 Bonnet U. An Overlooked Victim of Cannabis: Losing Several Years of Well-being and Inches of Jejunum on the Way to Unravel Her Hyperemesis Enigma. Clin Neuropharmacol. 2016 Jan-Feb;39(1):53-4.

118 Richards JR, Dutczak O. Propranolol Treatment of Cannabinoid Hyperemesis Syndrome: A Case Report. J Clin Psychopharmacol. 2017 Aug;37(4):482-4.

119 Lee LY, Abbott L, Mahlangu B, Moodie SJ, Anderson S. The management of cyclic vomiting syndrome: a systematic review. Eur J Gastroenterol Hepatol. 2012 Sep;24(9): 1001-6.

120 Ruffle JK, Bajgoric S, Samra K, Chandrapalan S, Aziz Q, Farmer AD. Cannabinoid hyperemesis syndrome: an important differential diagnosis of persistent unexplained vomiting. Eur J Gastroenterol Hepatol. 2015 Dec;27(12):1403-8.

121 Alaniz VI, Liss J, Metz TD, Stickrath E. Cannabinoid hyperemesis syndrome: a cause of refractory nausea and vomiting in pregnancy. Obstet Gynecol. 2015 Jun;125(6):1484-6.

122 Volkow ND, Compton WM, Wargo EM. The Risks of Marijuana Use During Pregnancy. JAMA. 2017 Jan;317(2):129-30.

123 Roberson EK, Patrick WK, Hurwitz EL. Marijuana use and maternal experiences of severe nausea during pregnancy in Hawai'i. Hawaii J Med Public Health. 2014 Sep;73(9): 283-7.

124 Committee on Obstetric Practice. Marijuana use during pregnancy and lactation. Committee Opinion No. 722. American College of Obstetricians and Gynecologists. Obstet Gynecol 2017;130:e205-9.
125 Sawni A, Vaniawala VP, Good M, Lim WY, Golec AS. Recurrent Cyclic Vomiting in Adolescents: Can It Be Cannabinoid Hyperemesis Syndrome? Clin Pediatr (Phila). 2016 Jun;55(6):560-3.

126 Gregoire P, Tau M, Robertson D. Cannabinoid hyperemesis syndrome and the onset of a manic episode. BMJ Case Rep. 2016 Apr 27;2016.

127 Gupta N, Ojo O, Muruthettuwegama K. Cannabinoid Hyper-emesis Syndrome: an Enigma. Indian J Psychol Med. 2013 Oct; 35(4):405-6.

128 Marillier M, Batisse A, Edel Y, Nguyen AH, Chevallier C, Pfau G, et al. Cannabinoid Hyperemesis Syndrome (CHS): A Parisian Case Series. J Clin Psychopharmacol. 2017 Dec;37(6):739-43.

129 Contreras Narváez C, Mola Gilbert M, Batlle de Santiago E, Bigas Farreres J, Giné Serven E, Cañete Crespillo J. Cannabinoid hyperemesis syndrome. A report of six new cases and a summary of previous reports. Adicciones. 2016 Mar;28(2):90-8.

130 Pélissier F, Claudet I, Gandia-Mailly P, Benyamina A, Franchitto N. Cannabis hyperemesis syndrome in the emergency department: how can a specialized addiction team be useful? A pilot study. J Emerg Med. 2016 Nov;51(5):544-51.

131 Schreck B, Wagneur N, Caillet P, Gérardin M, Cholet J, Spadari M, et al. Cannabinoid hyperemesis syndrome: review of the literature and of cases reported to the French addictovigilance network. Drug Alcohol Depend. 2018 Jan;182:27-32.

132 Beech RA, Sterrett DR, Babiuk J, Fung H Cannabinoid Hyperemesis Syndrome: A Case Report and Literature Review. J Oral Maxillofac Surg. 2015;73(10):1907-10.

133 Brewerton TD, Anderson O. Cannabinoid hyperemesis syndrome masquerading as an eating disorder. Int J Eat Disord. 2016 Aug. 49(8):826-9.

134 Braver O, Leibman Y. Cannabinoid Hyperemesis Syndrome: Descriptive Overview of an Under-Recognized Diagnosis. Isr Med Assoc J. 2015 May;17(5):324-5.

135 Desjardins N, Jamoulle O, Taddeo D, Stheneur C. Cannabinoid Hyperemesis Syndrome in a 17-Year-Old Adolescent. J Adolesc Health. 2015;57(5):565-7.

136 Cha JM, Kozarek RA, Lin OS. Case of cannabinoid hyperemesis syndrome with longterm follow-up. World J Clin Cases. 2014 Dec;2(12):930-3.

137 Habboushe J, Sedor J. Cannabinoid hyperemesis acute renal failure: a common sequela of cannabinoid hyperemesis syndrome. Am J Emerg Med. 2014 Jun;32(6):690.e1-2.

138 Baron M, Haymann JP, Wolfromm A, Rondeau E, Mesnard L. The Case I The smoker and the nephrologist. Kidney Int. 2011 Jun; 79(12):1385-6.

139 Heise L. Cannabinoid hyperemesis syndrome. Adv Emerg Nurs J. 2015 Apr-Jun; 37(2):95-101. 
140 Hermes-Laufer J, Del Puppo L, Inan I, Troillet FX, Kherad O. Cannabinoid Hyperemesis Syndrome: A Case Report of Cyclic Severe Hyperemesis and Abdominal Pain with Long-Term Cannabis Use. Case Rep Gastrointest Med. 2016;2016:2815901.

141 Ishaq S, Ismail S, Ghaus S, Roop-E-Zahra, Rostami K. Cannabinoid hyperemesis should be recognised as an effect of chronic cannabis abuse. Gastroenterol Hepatol Bed Bench. 2014;7(3):173-6.

142 Kast KA, Gershengoren L. Cannabinoid Hyperemesis Syndrome and the Consulting Psychiatrist: A Case Study of Diagnosis and Treatment for an Emerging Disorder in Psychiatric Practice. J Psychiatr Pract. 2018 Jan; 24(1):51-5.

143 Kraemer RR, La Hoz RM, Willig JH. Some like it hot: erythema ab igne due to cannabinoid hyperemesis. J Gen Intern Med. 2013 Nov;28(11):1522.

144 Mahmad AI, Jehangir W, Littlefield JM 2nd, John S, Yousif A. Cannabis hyperemesis syndrome: A case report review of treatment. Toxicol Rep. 2015 Jun;2:889-90.

145 Rajaram Manoharan SV, Aggarwal R, Taneli T. Cannabinoid hyperemesis syndrome: A case report. Asian J Psychiatr. 2018 Apr;34:64.

146 Miller JB, Walsh M, Patel PA, Rogan M, Arnold C, Maloney M, et al. Pediatric cannabinoid hyperemesis: two cases. Pediatr Emerg Care. 2010 Dec;26(12):919-20.

147 Mohammed F, Panchoo K, Bartholemew M, Maharaj D. Compulsive showering and marijuana use - the cannabis hyperemisis syndrome. Am J Case Rep. 2013 Aug;14:326-8.

148 Morris R, Fisher M. Cannabinoid hyperemesis syndrome: a specific cause of cyclical vomiting. Int J Adolesc Med Health. 2014; 26(1):153-6.

149 Nicolson SE, Denysenko L, Mulcare JL, Vito JP, Chabon B. Cannabinoid hyperemesis syndrome: a case series and review of previous reports. Psychosomatics. 2012 May-Jun; 53(3):212-9.

150 Nogi M, Fergusson D, Chiaco JM. Mid-ventricular variant takotsubo cardiomyopathy associated with Cannabinoid Hyperemesis Syndrome: a case report. Hawaii J Med Public Health. 2014 Apr;73(4):115-8.

151 Parekh JD, Wozniak SE, Khan K, Dutta SK Cannabinoid hyperemesis syndrome. BMJ Case Rep. 2016 Jan 20;2016.

152 Price SL, Fisher C, Kumar R, Hilgerson A. Cannabinoid hyperemesis syndrome as the underlying cause of intractable nausea and vomiting. J Am Osteopath Assoc. 2011 Mar; 111(3):166-9.
153 Ramadurai S, Gopalan S, Arthur P. Cannabinoid hyperemesis syndrome as an unusual cause of cyclic vomiting. Indian J Psychiatry. 2016 Apr-Jun;58(2):234-5.

154 Roca-Pallín JM, López-Pelayo H, Sugranyes G, Balcells-Oliveró MM. Cannabinoid hyperemesis syndrome. CNS Neurosci Ther. 2013 Dec;19(12):994-5.

155 Roche E, Foster PN. Cannabinoid hyperemesis: not just a problem in Adelaide Hills. Gut. 2005 May;54(5):731.

156 Sannarangappa V, Tan C. Cannabinoid hyperemesis. Intern Med J. 2009 Nov;39(11): 777-8.

157 Schmid SM, Lapaire O, Huang DJ, Jürgens FE, Güth U. Cannabinoid hyperemesis syndrome: an underreported entity causing nausea and vomiting of pregnancy. Arch Gynecol Obstet. 2011 Nov;284(5):1095-7.

158 Singh E, Coyle W. Cannabinoid hyperemesis. Am J Gastroenterol. 2008 Apr;103(4): 1048-9.

159 Sontineni SP, Chaudhary S, Sontineni V, Lanspa SJ. Cannabinoid hyperemesis syndrome: clinical diagnosis of an underrecognised manifestation of chronic cannabis abuse. World J Gastroenterol. 2009 Mar; 15(10):1264-6.

160 Torka P, Sharma R. Cannabinoid and hyperemesis. Mayo Clin Proc 2012;87(5):502-503; author reply 503 .

161 Wallace D, Martin AL, Park B. Cannabinoid hyperemesis: marijuana puts patients in hot water. Australas Psychiatry. 2007; 15(2):156-8.

162 Warner B, Cairns S, Stone A. A rare case of cannabis hyperemesis syndrome relieved by hot water bathing. Clin Med (Lond). 2014 Feb;14(1):86-7.

163 Wild K, Wilson H. Cannabinoid hyperemesis. Emerg Med J. 2012 Jan;29(1):67-9.

164 Williamson JE, July M, Gonzalez LM, Amin $\mathrm{HH}$, Chaudhari S. Cannabinoid hyperemesis syndrome: cyclical vomiting behind the cloud of smoke. Am J Med. 2014 Apr; 127(4):e1-2.

165 Woods JA, Wright NJ, Gee J, Scobey MW. Cannabinoid Hyperemesis Syndrome: An Emerging Drug-Induced Disease. Am J Ther. 2016 Mar-Apr;23(2):e601-5.

166 Argamany JR, Reveles KR, Duhon B. Synthetic cannabinoid hyperemesis resulting in rhabdomyolysis and acute renal failure. Am J Emerg Med. 2016 Apr;34(4):765.e1-2.

167 Bick BL, Szostek JH, Mangan TF. Synthetic cannabinoid leading to cannabinoid hyperemesis syndrome. Mayo Clin Proc. 2014; 89(8):1168-9.
168 Hopkins CY, Gilchrist BL. A case of cannabinoid hyperemesis syndrome caused by synthetic cannabinoids. J Emerg Med. 2013 Oct;45(4):544-6.

169 Ukaigwe A, Karmacharya P, Donato A. A Gut Gone to Pot: A Case of Cannabinoid Hyperemesis Syndrome due to K2, a Synthetic Cannabinoid. Case Rep Emerg Med. 2014;2014:167098.

170 Heard K, Marlin MB, Nappe T, Hoyte CO Common marijuana-related cases encountered in the emergency department. Am J Health Syst Pharm. 2017 Nov;74(22):19048.

171 Nourbakhsh M, Miller A, Gofton J, Jones G, Adeagbo B. Cannabinoid hyperemesis syndrome: reports of fatal cases. J Forensic Sci. 2018 May. https://doi.org/10.1111/15564029.13819.

172 Trappey BE, Olson AP. Running out of options: rhabdomyolysis associated with cannabis hyperemesis syndrome. J Gen Intern Med. 2017 Dec;32(12):1407-9.

173 Valdivielso Cortazar E, Ucha Abal P, Alonso Aguirre P. Cannabinoid hyperemesis syndrome. Rev Esp Enferm Dig. 2018;110(5): 334-5.

174 Hudson JI, Hiripi E, Pope HG Jr, Kessler RC. The prevalence and correlates of eating disorders in the National Comorbidity Survey Replication. Biol Psychiatry. 2007 Feb;61(3): 348-58.

175 Bramstedt J, Dissmann R. [Cannabinoid hyperemesis syndrome inducing acute prerenal failure and electrolyte disturbance]. Dtsch Med Wochenschr. 2011;136(34-35): $1720-2$.

176 Felsenfeld AJ, Levine BS. Approach to treatment of hypophosphatemia. Am J Kidney Dis. 2012 Oct;60(4):655-61.

177 Amanzadeh J, Reilly RF Jr. Hypophosphatemia: an evidence-based approach to its clinical consequences and management. Nat Clin Pract Nephrol. 2006 Mar;2(3):136-48.

178 Cadman PE. Hypophosphatemia in Users of Cannabis. Am J Kidney Dis. 2017 Jan;69(1): $152-5$.

179 National Institute on Drug Abuse. Nationwide Trends. 2015; https://www.drugabuse. gov/publications/drugfacts/nationwidetrends. Accessed May 26, 2018.

180 Manning Meurer M, Chakrala K, Gowda D, Burns C, Kelly R, Schlabritz-Loutsevitch N. A case of cannabinoid hyperemesis syndrome with Heliobacter pylori and preeclampsia during pregnancy. Subst Abus. 2018 Jan;39(1):9-13. 